\title{
Water Saving and Yield of Potatoes under Partial Root-Zone Drying Drip Irrigation Technique: Field and Modelling Study Using SALTMED Model in Saudi Arabia
}

\author{
Abdulrasoul Al-Omran ${ }^{1, * \mathbb{C}}$, Ibrahim Louki ${ }^{1}$, Arafat Alkhasha ${ }^{1,2}$, \\ Mohamed Hassan Abd El-Wahed ${ }^{3}$ and Abdullah Obadi ${ }^{4}$ \\ 1 Soil Science Department, College of Food and Agricultural Sciences, King Saud University, Riyadh 11451, \\ Saudi Arabia; ibrahim.louki@hotmail.com (I.L.); aakhasha@ksu.edu.sa (A.A.) \\ 2 General Authority for Agricultural Research, El-Kod Station, Aden 1837, Yemen \\ 3 Arid Land Agriculture Department, Faculty of Meteorology, Environment and Arid Land Agriculture, \\ King Abdulaziz University, Jeddah 80208, Saudi Arabia; mhassan1@kau.edu.sa \\ 4 Department of Plant Production, College of Food and Agricultural Sciences, King Saud University, \\ Riyadh 11451, Saudi Arabia; obadi201@gmail.com \\ * Correspondence: rasoul@ksu.edu.sa; Tel.: +966-11467844; Fax: +966-114678440
}

Received: 28 November 2020; Accepted: 16 December 2020; Published: 19 December 2020

\begin{abstract}
This study aims to evaluate the Partial Root Zone Drying Irrigation System (PRD) as one of the modern technologies that provide irrigation water and increase the efficiency of its use on potato crop. The effect of applying the PRD conventional deficit irrigation (CDI) on the efficiency and water saving in potato crops using the drip surface (S) and subsurface (SS) irrigation methods were investigated. SALTMED model used to predict soil moisture and salinity distribution, soil nitrogen dynamics, and yield of potato crop using the different irrigation levels $(150 \%, 100 \%$, and $50 \%$ of Crop evapotranspiration (ETc)). The study showed that the water use efficiency (WUE) decreases with increasing levels of irrigation water, as it ranged between 2.96 and $8.38 \mathrm{kgm}^{-3}, 2.77$ and $7.01 \mathrm{kgm}^{-3}$ for surface irrigation PRD and CDI, respectively, when the amounts of irrigation water varied from $308 \mathrm{~mm}$ to $1174 \mathrm{~mm}$, respectively. The study showed that the irrigation efficiencies were the highest when using PRD system in all treatments when irrigating the potato crop during the spring season, and it was more efficient in the case of using subsurface irrigation method. The results show that the soil moisture (SM) was high in $25-45 \mathrm{~cm}$ at $150 \%$ of ETc was 0.166 and $0.263 \mathrm{~m}^{3} \mathrm{~m}^{-3}$ for the first and last stages of growth, respectively. $100 \%$ of ETc, (SM) was $0.296 \mathrm{~m}^{3} \mathrm{~m}^{-3}$ at $0-25 \mathrm{~cm}$, $0.195 \mathrm{~m}^{3} \mathrm{~m}^{-3}$ at $25-45 \mathrm{~cm}, 0.179 \mathrm{~m}^{3} \mathrm{~m}^{-3}$ at $45-62 \mathrm{~cm}$, depths, respectively. whereas $50 \%$ of ETc, (SM) was $0.162 \mathrm{~m}^{3} \mathrm{~m}^{-3}$ at $0-25 \mathrm{~cm}, 0.195 \mathrm{~m}^{3} \mathrm{~m}^{-3}$ at $25-85 \mathrm{~cm}$, depths. At $100 \%$ of ETc, soil salinity was $5.15,4.37,3.3$, and $4.5 \mathrm{dSm}^{-1}$, whereas at 50\%, ETc, these values were 5.64, 9.6, 3.3, and $4.2 \mathrm{dSm}^{-1}$. Statistical indicators showed that the model underestimated yield, for $150 \%, 100 \%$, and $50 \%$ of ETc. Therefore, it can be concluded that yield and WUE using PRD systems were the highest in the potato crop compare to CDI surface and sub-surface, and SALTMED model can predict the moisture distribution, salinity, and yield of potatoes after accurate adjustment.
\end{abstract}

Keywords: partial root-zone drying; SALTMED model; potato crop; irrigation levels

\section{Introduction}

Irrigation is the most critical factor for agricultural production, especially in areas with limited water resources and low annual rainfall, such as arid regions. Saudi Arabia is located in the arid 
region; thus, it is critical to consider the quantities of irrigation water and methods of application for any irrigation water management practices. Therefore, modern irrigation systems, such as drip irrigation combined with deficit irrigation (DI) or partial root-zone drying (PRD) system techniques could be useful for saving water. Applying both DI and PRD resulted in the conservation of large quantities of irrigation water and increased yield. Furthermore, using mathematical models helped save time for decision-makers to manage irrigation water and forecast production under different conditions [1], and to study other factors affecting yield, such as soil moisture, salt distribution, and nitrogen concentration in the soil profile.

\subsection{PRD Irrigation Technique}

PRD is an irrigation technique that stimulates partial stomatal closing to decease transpiration into leaves, improves water use efficiency, and increases the yield. PRD includes processes of alternative wetting and drying of both sides of the plant zone to optimize the production of root-sourced chemical signals, which is related to water deficits [2-5]. The PRD technique stimulates some responses associated with drying soil, such as reduced energy and stomatal conductance (gs) while preserving adequate water supply within the wetted part of the root zone to maintain conventional crop growth [6]. This technique of irrigation is very important mainly in arid regions such Saudi Arabia as water resources are very limited. The irrigation water using PRD can be conserved and saved until 50\% evapotranspiration without significant reductions in yield.

\subsection{SALTMED Model}

The SALTMED model includes parameters, such as crop evapotranspiration, water uptake, and solute transport under different irrigation systems, drainage, and the relationship between crop yield and water use [7]. Marwa et al. (2020) [8] reported that the SALTMED model is efficient for predicting total dry matter and yield. The SALTMED model can run with different scenarios under different conditions and crop parameters to evaluate the future impact on irrigation management and predict water distribution under automatic irrigation scheduling. Alkhasha and Al-Omran (2019) [9] highlighted that the SALTMED model is reliable for predicting soil moisture and salinity distribution of tomato yield. Kaya and Yazar (2016) [10] concluded that the SALTMED model can be used to compare the simulated and measured soil water content. They found significant yield decreased in 2010 , but slightly reduced the high salinity of water from $10-30 \mathrm{dSm}^{-1}$ compared with non-saline water in 2012. The results showed that the model can predict soil water, grain, and dry matter yield of quinoa with a deficit irrigation regime using different water qualities [11].

Kaya et al. (2015) [11] highlighted that the SALTMED model can simulate high relation between soil moisture, total dry matter, and grain yield for quinoa in different irrigation arid environments. The SALTMED model could accurately predict the distribution in the soil profile of salt and soil water content of different crop yields grown under several irrigation demands and environmental conditions. Pulvento et al. (2013) [12] reported that the SALTMED model can predict quinoa crop in Italy under saline and freshwater conditions with high relation between the observed and simulated soil moisture and yield. Abdelraouf and Ragab (2017) [13] concluded that using the model could have reliable results for soil moisture and nitrogen dynamics. Abdelraouf and Ragab (2018) [14] reported that simulating total dry matter, yield, and water yield using the SALTMED model gave good results between the observation and simulation during two seasons (2015 and 2016), with $R^{2}=0.99$. The SALTMED model used in Syria by Gawad et al. (2005) [15] showed the impact of the irrigation method on the soil class, the salinity of irrigation water on soil moisture, and salinity distribution. The results demonstrated that the SALTMED model is useful in the management of water, crops, and soil under field conditions. Ragab et al. (2005) [1] reported that the relationship between both yield and water uptakes as a function of water salinity was nonlinear and defined by a polynomial function of the fourth-order. The relative yield and water uptake obtained by dividing the estimated values by equal values obtained using $100 \%$ freshwater alleviated the effect of external factors and produced 
consistent and reliable results. Studies conducted by Hirich et al. (2012) [16] and Silva et al. (2013) [17] concluded that SALTMED could make simulations in daily basis according to the main processes of the soil-water-plant relationship. Recently, the model was used on sweetcorn, quinoa, and chickpea and could effectively simulate final yield, moisture, and nitrogen profiles [8,18-20]. It is an important means in scheduling irrigation in a scientifically documented manner with the aim of saving water consumptions and providing an opportunity for horizontal expansion in agriculture by exploiting the limited quantities of water supplied with it, and setting priorities in the use of limited irrigation water.

Therefore, the aim of the study is to introduce all water saving programs such as deficit irrigation and PRD to farmers and examines the SALTMED model to predict soil moisture and soil salinity distributions, soil nitrogen dynamics, and yield of potato crops using the PRD irrigation technique.

\section{Materials and Methods}

\subsection{Location}

This study was conducted from 2014-2018 in the agricultural project in Thadeq Governorate,

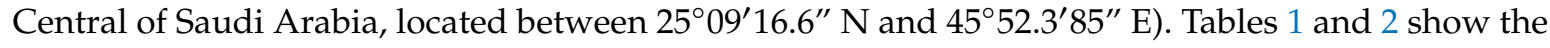
properties (chemical and physical) of soil and irrigation water of the location used in field experiments.

Table 1. Properties of soil and water.

\begin{tabular}{ccccccccc}
\hline Location & Sand $\%$ & Silt\% & Clay\% & Soil Texture & $\begin{array}{c}\text { Bulk Density } \\
\mathbf{g c m}^{-3}\end{array}$ & O.M\% & CaCo $_{\mathbf{3}} \%$ & S.P\% \\
\hline 1 & 75 & 15 & 10 & Sandy Loam & 1.51 & 1.1 & 18.8 & 26 \\
2 & 80 & 7.5 & 12.5 & Sandy Loam & 1.56 & 0.9 & 19.9 & 24 \\
\hline
\end{tabular}

Table 2. Chemical properties of soil and water.

\begin{tabular}{|c|c|c|c|c|c|c|c|c|c|c|}
\hline \multirow{2}{*}{ Sample } & \multirow{2}{*}{ pH } & \multirow{2}{*}{$\begin{array}{c}\text { E.C } \\
\mathrm{dS} \cdot \mathrm{m}^{-1}\end{array}$} & \multicolumn{4}{|c|}{ Cations (meq $\mathrm{L}^{-1}$ ) } & \multicolumn{3}{|c|}{ Anions (meq L ${ }^{-1}$ ) } & \multirow{2}{*}{ SAR } \\
\hline & & & $\mathrm{Ca}^{+2}$ & $\mathrm{Mg}^{+2}$ & $\mathrm{Na}^{+1}$ & $\mathrm{~K}^{+1}$ & $\mathrm{Cl}^{-1}$ & $\mathrm{HCO}_{3}{ }^{-1}$ & $\mathrm{SO}_{4}^{-2}$ & \\
\hline Location Soil (1) & 7.27 & 13.61 & 55.2 & 22.5 & 35.78 & 12.72 & 53 & 9.9 & 63.7 & 5.74 \\
\hline Location Soil (2) & 7.49 & 3.74 & 17.4 & 10.3 & 7.52 & 3.03 & 12.5 & 3.5 & 22.25 & 2.02 \\
\hline Irrigation Water & 7.6 & 1.6 & 6.55 & 5 & 4.33 & 0.17 & 5.46 & 3.49 & 6.21 & 1.8 \\
\hline
\end{tabular}

\subsection{Climate}

The area has hot, dry continental weather in summer and is cold in winter. Temperatures reach above $50{ }^{\circ} \mathrm{C}$ in summer, with an average of $44.9^{\circ} \mathrm{C}$ [21] and can drop to below $-4.4{ }^{\circ} \mathrm{C}$ in winter, with an average of $8^{\circ} \mathrm{C}$. The rain season is in the winter but irregular, averaging $101 \mathrm{~mm}$ per year [21]. Table 3 illustrates the average climate conditions dominating in the study area from 1998-2018. 
Table 3. The average of climate conditions in the study area 1998-2018.

\begin{tabular}{|c|c|c|c|c|c|c|c|c|c|}
\hline \multirow[t]{2}{*}{ Months } & \multicolumn{2}{|c|}{ Temperature ${ }^{\circ} \mathrm{C}$} & \multicolumn{2}{|c|}{ Relative Humidity \% } & \multirow{2}{*}{$\begin{array}{l}\text { Wind Speed } \\
\text { at } 2 \mathrm{~m} \mathrm{~ms} \mathrm{~ms}^{-1}\end{array}$} & \multirow{2}{*}{$\begin{array}{c}\text { Evaporation } \\
\text { mm }\end{array}$} & \multirow{2}{*}{ Soil Temperature } & \multirow{2}{*}{$\begin{array}{l}\text { Radiation Langley } \\
\text { day }^{-1}\end{array}$} & \multirow{2}{*}{$\begin{array}{c}\text { Hour of Sunshine } \\
\text { H day }^{-1}\end{array}$} \\
\hline & Max. & Min. & Max. & Min. & & & & & \\
\hline January & 20.2 & 7.2 & 67 & 25 & 2.7 & 3.8 & 17 & 226 & 6.7 \\
\hline February & 23.8 & 9.5 & 55 & 23 & 3.2 & 5.7 & 17.7 & 306 & 7.5 \\
\hline March & 29.3 & 13.7 & 49 & 18 & 3.2 & 7.6 & 20.4 & 346 & 7.4 \\
\hline April & 34.9 & 19.1 & 47 & 17 & 3.5 & 10.1 & 25.5 & 391 & 7.8 \\
\hline May & 40.3 & 24.1 & 35 & 14 & 3.5 & 13.0 & 30.0 & 422 & 8.5 \\
\hline June & 43.3 & 25.9 & 26 & 12 & 3 & 14.5 & 32.1 & 468 & 10.2 \\
\hline July & 44.2 & 27.6 & 25 & 11 & 3 & 14.5 & 34.0 & 451 & 10.0 \\
\hline August & 44.6 & 27.4 & 30 & 13 & 2.8 & 13.6 & 34.4 & 437 & 10.2 \\
\hline September & 41.1 & 23.6 & 32 & 14 & 2.5 & 11.1 & 32.8 & 396 & 9.6 \\
\hline October & 36.0 & 18.2 & 42 & 17 & 2.1 & 8.5 & 28.1 & 345 & 8.7 \\
\hline November & 28.1 & 13.1 & 68 & 25 & 2.4 & 5.3 & 20.6 & 272 & 7.1 \\
\hline December & 23 & 8.2 & 62 & 22 & 2.7 & 3.7 & 16.2 & 227 & 6.5 \\
\hline
\end{tabular}




\subsection{Field Experiment}

The partial dry root-zone irrigation system (PRD) and deficit irrigation for potato experiments were carried out in the open field under surface and subsurface drip irrigation. The number of experimental units are 48 (for 16 treatments and 3 replicates), half of which are for Conventional Drip Irrigation (CDI), and the other half is a Partial Root-zone Drying Irrigation System (PRD). Each treatment is divided into surface drip irrigation (S) and Subsurface drip irrigation (SS). The area of each experimental unit in the open field is $12.5 \mathrm{~m}^{2}$ as presented in Figure 1.

\section{Irrigation Systens}

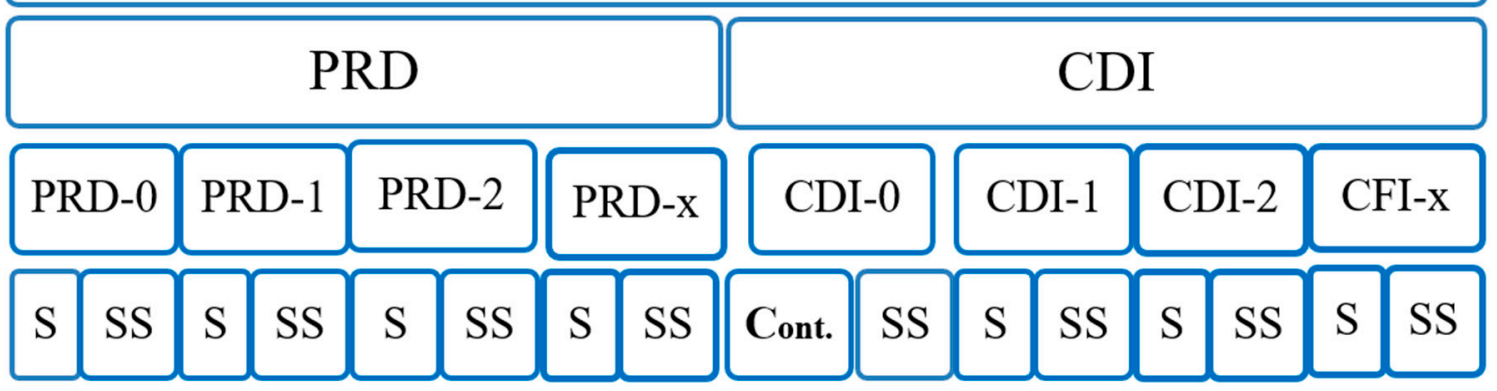

Figure 1. Layout of the experimental design for potato open field. PRD = Irrigation with a partial drying of the root zone with two double lines, with four irrigation levels. CDI = Single-line drip irrigation system, with four levels of irrigation: regular, incomplete and conventional. CFI $=$ full drip irrigation or high irrigation. $0,1,2, x$, = irrigation treatments at $100 \%, 75 \%, 50 \%$, and $150 \%$ of the planned irrigation water, respectively. Control: Irrigated with conventional standard irrigation (100\% conventional surface drip irrigation). S = drip irrigation. SS = subsurface drip irrigation.

Seed potatoes of the Dutch variety "Espunta" (Solanum tuberosum, NAK-NEDERLAND, the Netherlands) were planted, two seeds were planted in each seed hole and thinned to one after its germination ending up to an average of 4 plants per square meter. The experiments were carried out during (October 2014-May 2017).

\subsection{Fertilization}

Basic fertilization was carried out with granulated compound fertilizer with a formula $(12-12-17+2 \mathrm{Mg}+6 \mathrm{Ca}+\mathrm{TE})$ with a rate of $72 \mathrm{~kg} /$ ha-total nitrogen $(\mathrm{N}), 72 \mathrm{~kg} / \mathrm{ha}$-phosphate $\left(\mathrm{P}_{2} \mathrm{O}_{5}\right)$, and $102 \mathrm{~kg} / \mathrm{ha}$ - Potassium $\left(\mathrm{K}_{2} \mathrm{O}\right)$, was mixed with soil while preparing it for planting as a basis fertilizer. With the beginning of the third week of planting (the beginning of the second phase), the Fertigation program was implemented with dissolved fertilizers according to the growth stage. Soluble fertilizers were used in the formulation: 1:0.8:3:1.2:0.4:0.4:0.2 and at the rate of 25, 20, 75, 30, 10, 10 and $5 \mathrm{~kg} / \mathrm{ha}$ of elements (NPK $+\mathrm{Ca}+\mathrm{Mg}+\mathrm{Fe}+\mathrm{TE}$ ), respectively, weekly until Two weeks before the end of the season, when fertilizing was stopped permanently. In addition, humic acid was added $6 \%$ at a rate of $4 \mathrm{~L} /$ ha to the mixture in the fertigation tank. Calcium compounds were not mixed with the rest of the fertilizers for fear of sedimentation and clogging of the drippers. The drippers were cleaned by adding $93 \%$ phosphoric acid at a rate of $2 \mathrm{~L} / \mathrm{ha}$ (at a concentration of $0.06 \mathrm{~g} / \mathrm{L}$ ) to the tank on an irrigation day without fertilization.

\subsection{Daily Readings of Plant Environment Data}

The readings of climatic data devices were recorded in the open field daily, as well as readings of the evaporation pan, then using the computer to estimate the daily water needs for irrigation. The water meters were read and recorded before and after each irrigation, and compared to the total volume set for irrigation. The readings of the meters installed in the irrigation lines were recorded 
immediately before irrigation and four hours after irrigation. The state of soil moisture in the root zone was also measured periodically by weight method, to compare with estimates of moisture monitoring and measuring soil sensors devices, where samples were taken from each treatment before and after irrigation at a depth of $20 \mathrm{~cm}$ and were immediately weighed with a digital scale and then oven drying at $105^{\circ} \mathrm{C}$.

\subsection{Crop Water Requirement}

The crop Evapotranspiration (ETc) in the open field conditions was assessed through three methods namely: Lysimeters, Evaporation Pan, and on Penman-Monteith equation (PM).

\subsubsection{Lysimeters}

Eight groups of non-weighted lysimeters were prepared in the main crop fields with three equal replications for the potatoes and alfalfa as reference with total of 24 experimental units. The lysimeters of the galvanized sheet lined are equipped with a thermal insulator with dimensions of $3.93 \times 1 \times 1 \mathrm{~m}$ at site No. 1, and with dimensions of $2 \times 1 \times 1 \mathrm{~m}$ in the open field. Each lysimeter was filled with fine gravel at a height of $15 \mathrm{~cm}$ [22], and then added alluvial sandy soil similar to that of the experimental fields (Figure 2).
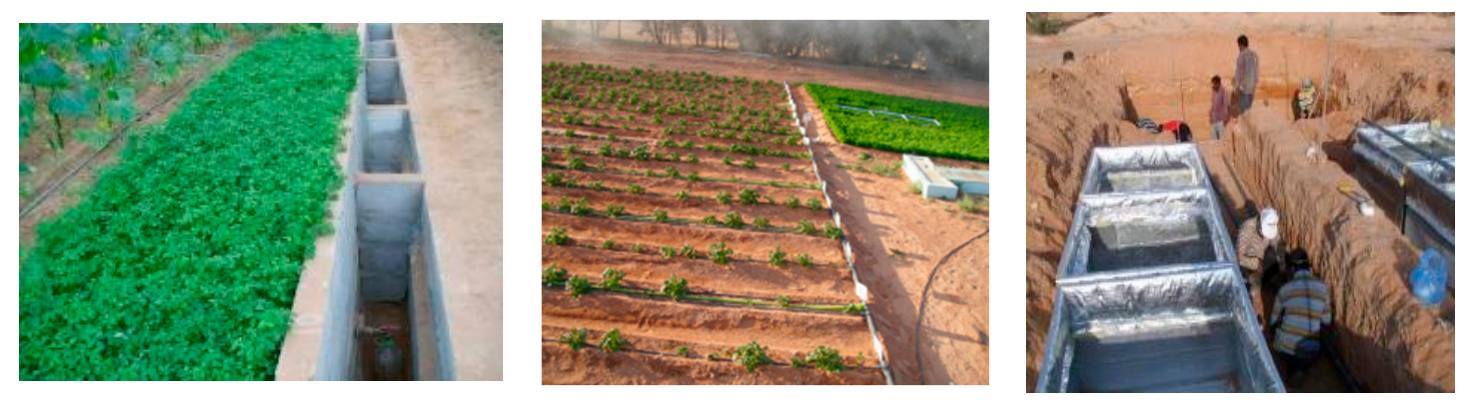

Figure 2. The installation of the lysimeters to determine Crop evapotranspiration (ETc.)

The ETc of potato crops was calculated by directly calculating the quantities of ETc from their lysimeters by applying the water balance formula [23]:

$$
\mathrm{ETc}=\mathrm{P}+\mathrm{I}-\mathrm{DP} \pm \Delta \mathrm{SW}
$$

where:

ETc $=$ Crop evapotranspiration - crop (in $\mathrm{mm}$ ) over a period of time.

$\mathrm{I}=$ depth of water added by irrigation during a specified time period in $\mathrm{mm}$.

$\mathrm{P}=$ amount of rainfall during the same time period in $\mathrm{mm}$.

$\mathrm{DP}=$ amount of drainage (in $\mathrm{mm}$ ) during the same time period.

$\Delta S W=$ change in soil moisture content over the same time period in $\mathrm{mm}$.

The value of the crop coefficient $(\mathrm{Kc})$ was calculated from crop evapotranspiration (ETc) and reference evapotranspiration of alfalfa ETr directly from the lysimeters (Table 4). In addition, Kc values were calculated by the evaporation pan method (E-pan) as well as from the Penman-Monteith (PM) equation. The crop coefficient for potato and for the reference alfalfa was calculated according to [23] Table 4. Means of total irrigation water added per season of potato crop during the lysimeter experiments (2014-2017) are shown in Table 5. 
Table 4. Mean Kc for the main growth stages during the spring and fall seasons taking the alfalfa as a reference for comparison.

\begin{tabular}{ccccc}
\hline Growth Stage & No. of Days after Planting & Kc-Evap. Pan & Kc-PM Methods & Kc-Alfalfa \\
\hline \multicolumn{2}{c}{ Spring Season } & & & \\
\hline Kc (ini) early & 1 & 0.69 & 0.55 & 0.50 \\
\hline Kc(ini) end & 20 & 0.69 & 0.55 & 0.50 \\
\hline Kc (mid) early growth season & 47 & 1.00 & 1.16 & 0.91 \\
\hline Kc (mid) early late growth season & 83 & 1.44 & 1.16 & 0.91 \\
\hline Kc end of season & 98 & 1.37 & 1.05 & 0.79 \\
\hline Fall season & & & & 0.52 \\
\hline Kc (ini) early & 1 & 0.69 & 0.76 & 0.52 \\
\hline Kc(ini) end & 20 & 0.69 & 0.76 & 0.93 \\
\hline Kc (mid) early growth season & 47 & 1.20 & 1.41 & 0.93 \\
\hline Kc (mid) early late growth season & 70 & 1.20 & 1.41 & 0.65 \\
\hline Kc end of season & 79 & 0.88 & 1.07 & \\
\hline
\end{tabular}

Table 5. Means of total irrigation water added per season of potato crop during the lysimeter experiments (2014-2017).

\begin{tabular}{ccc}
\hline Method of Calculation of ETc & Spring Season & Fall Season \\
\hline Actual water added at $100 \%$ & 616.0 & 582.2 \\
\hline Lysimeter using reference crop & 740.0 & 642.2 \\
\hline Evaporation Pan & 532.0 & 748.0 \\
\hline Penman-Monteith & 546.0 & 974.0 \\
\hline RMSE & 1.09 & 1.77 \\
\hline
\end{tabular}

\subsubsection{Pan Evaporation}

A pan and adequate weather data station equipment were installed to obtain data weather as well as evaporation pan data [23]. Crop evapotranspiration (ETc) was calculated using the following equation: $\mathrm{ETc}=\mathrm{Ep} \times \mathrm{Kp} \times \mathrm{Kc}$, where ETc is maximum daily crop ET in mm, Ep standing for the daily evaporation from class A Pan in $\mathrm{mm}, \mathrm{Kp}$ is the pan coefficient (ranging between 0.70 and 0.88 ), and $\mathrm{Kc}$ is the crop coefficient (ranging between 0.50 and 1.44) depending on growth stages (Table 4). Kp and Kc were found out according to the equations of Allen et al. (1998). The Gross Water Requirement (GWR) was calculated by the following equations: GWR $=\mathrm{ETc} /(1-\mathrm{LR}), \mathrm{GWR}=\mathrm{Kc} \times \mathrm{Eo} \times \mathrm{Kp} /(1-\mathrm{LR}) \times \mathrm{Ea}$, where, GWR is Gross Water Requirement in $\mathrm{mm} \mathrm{day}^{-1}$, Ea is irrigation efficiency, and LR the leaching requirement. LR was calculated according to Ayers and Westcot (1985): LR $=\mathrm{ECw} \times(\mathrm{El} / 2 \mathrm{ECe}$ max) where, $\mathrm{ECW}$ is salinity of irrigation water in $\mathrm{dSm}^{-1}, \mathrm{El}$ is leaching efficiency, and ECe max the maximum electrical conductivity of the extracted soil paste for zero yield in $\mathrm{dSm}^{-1}$. The calculated LR in this experiment amounted to 0.06 .

\subsubsection{Penman-Monteith}

The combined FAO Penman-Monteith method was used to calculate $\mathrm{ET}_{\mathrm{o}}$ or using pan evaporation methods.

\subsection{SALTMED Model}

The full process of calibration, validation, and data required to run the SALTMED model are addressed in our previous study [9]. The data required to run the model are related to crop parameters, soil parameters, meterological daily data, and irrigation data as reported by Alkhasha and Alomran (2019) [9]. 
Model Statistical Analyses

To define agreement data measured and predicted values for treatments, statistical indicators were used. The root mean square error (RMSE) (Equation (2)) value can be calculated as

$$
\mathrm{RMSE}=\sqrt{\sum_{i=1}^{n}(\mathrm{O} i-S i)^{2} / n},
$$

where $O i$ is the observed value $i, S i$ is the simulated value, and $n$ is the number of treatments.

The coefficient of residual mass (CRM) [24] is defined by

$$
C R M=\frac{\sum_{i=1}^{n} O i-\sum_{i=1}^{n} S i}{\sum_{i=1}^{n} O i} .
$$

CRM measures whether the tendency of the value (negative) overestimates or (positive) underestimates the measurements.

The coefficient of determination $\left(R^{2}\right)$ is determined by regression analysis between the observed and simulated values using

$$
R^{2}=\frac{\left[\sum_{i=1}^{n}\left(O i-O_{a v g}\right)\left(S i-S_{a v g}\right)\right]^{2}}{\sum_{i=1}^{n}\left(O i-O_{a v g}\right)^{2} \sum_{i=1}^{n}\left(S i-S_{a v g}\right)^{2}}
$$

where $O i$ is the observed value $i, O_{a v g}$ is a mean of values, $S i$ is the $g$-simulated value, $S_{a v g}$ is a mean of values, and $n$ is the number of treatments.

The mean relative error (MRE) indicates whether the model is underpredicting or overpredicting the observed value.

$$
\operatorname{MRE}=\frac{\sum_{i=1}^{n}\left(S_{i}-O_{i}\right)}{n},
$$

where $O i$ is the observed value $i, S i$ is the simulated value, and $n$ is the number of observed or simulated values.

\section{Results}

\subsection{Potato Crop Water Requirements}

Potato crop water requirements were estimated according to the evaporation pan method as the main method for daily irrigation while the FAO/Penman-Monteith method was calculated for scrutiny and comparison Table 5. The results showed an increase in the irrigation water for the spring season compared to the fall season in all repeated runs of the experiments, as well as an increase in the quantities of water calculated by the Penman-Monteith method over the calculated pan evaporation method for the same season during the spring seasons, while it decreased slightly in the fall seasons. The seasonal reference evapotranspiration calculated by the evaporation pan method during the fall and spring seasons 532 and $748 \mathrm{~mm}$ with daily averages of 5.4 and $6.5 \mathrm{~mm} /$ day respectively, while the FAO/Penman-Monteith method were 546 and $975 \mathrm{~mm}$ with a daily average of 5 and $8.5 \mathrm{~mm} /$ day, respectively.

\subsection{Potato Yield}

In this study the yield of $100 \%$ surface conventional drip irrigation treatment was taken as a standard basis for comparison of all potato harvest results for all treatments (Table $6 a, b)$ for spring and fall seasons. The results of the statistical analysis using LSD $_{05}$ showed the extent to which the yield of any treatment increased or decreased over the standard treatment (100 of ETc). Table 6a showed that at PRD-SS yield decreased by 5.1\% compared to PRD-S treatment with a slight increase 
in the conventional subsurface irrigation CDI-SS by $2.6 \%$ (Table 6a), but at the level of irrigation of $75 \%$ ETc the yield decrease by $6,17.8,12.7$, and $22 \%$ for the PRD-S, PRD-SS, DI-S, and DI-SS irrigation system, respectively. The results showed that the yield of the PRD-S treatment with was lower when the irrigation was reduced by $75 \%$ of ETc, while when the irrigation level was reduced to $50 \%$, the percentage decrease in the yield was $14.8,23.2,13.9$, and $25.8 \%$ for the PRD-S, PRD-SS, DI-S, and DI-SS, respectively. The results of fall season showed the same trend with the exception that at $100 \%$ ETc CDI gave a slight increase in yield compared to the PRD method (Table $6 \mathrm{~b}$ ).

Table 6. (a) Yield of potato as affected by PRD, deficit irrigation (DI), and full irrigation (Spring season). (b) Yield of potato as affected by PRD, DI, and full irrigation (Fall season).

\begin{tabular}{|c|c|c|c|c|c|c|c|c|c|c|}
\hline \multicolumn{11}{|c|}{ (a) } \\
\hline $\begin{array}{c}\text { ETc } \\
\text { Calculated } \\
(\mathrm{mm})\end{array}$ & $\begin{array}{l}\text { Applied } \\
\text { Water } \\
(\mathrm{mm})\end{array}$ & ETc \% & $\begin{array}{c}\text { Yield } \\
\text { PRD-S } \\
\left(\mathrm{Kg} / \mathrm{m}^{2}\right)\end{array}$ & $\begin{array}{c}\text { WUE } \\
\mathrm{Kg} / \mathrm{m}^{3}\end{array}$ & $\begin{array}{c}\text { Yield } \\
\text { PRD-SS } \\
\left(\mathrm{Kg} / \mathrm{m}^{2}\right)\end{array}$ & $\begin{array}{c}\text { WUE } \\
\mathrm{Kg} / \mathrm{m}^{3}\end{array}$ & $\begin{array}{c}\text { Yield } \\
\text { CDI-S } \\
\left(\mathrm{Kg} / \mathrm{m}^{2}\right)\end{array}$ & $\begin{array}{c}\text { WUE } \\
\mathrm{Kg} / \mathrm{m}^{3}\end{array}$ & $\begin{array}{c}\text { Yield } \\
\text { CDI-SS } \\
\left(\mathrm{Kg} / \mathrm{m}^{2}\right)\end{array}$ & $\begin{array}{c}\text { WUE } \\
\mathrm{Kg} / \mathrm{m}^{3}\end{array}$ \\
\hline \multicolumn{11}{|c|}{ Spring Seasons } \\
\hline 616 & 783 & 100 & 3.17 & 4.05 & 3.11 & 3.97 & 3.21 & 4.10 & 3.26 & 4.16 \\
\hline 616 & 783 & 100 & 3.44 & 4.40 & 3.32 & 4.24 & 3.59 & 4.48 & 3.62 & 4.62 \\
\hline 616 & 783 & 100 & 3.66 & 4.67 & 3.27 & 4.18 & 3.43 & 4.38 & 3.60 & 4.60 \\
\hline Mean & & & $3.42^{b}$ & 4.37 & $3.23 \mathrm{bc}$ & 4.12 & $3.41^{b}$ & 4.36 & $3.50^{\mathrm{ab}}$ & 4.47 \\
\hline 462 & 587 & 75 & 3.33 & 5.67 & 2.55 & 4.34 & 2.98 & 4.92 & 2.59 & 4.41 \\
\hline 462 & 587 & 75 & 2.99 & 5.09 & 2.98 & 5.07 & 3.03 & 5.16 & 2.66 & 4.53 \\
\hline 462 & 587 & 75 & 3.33 & 5.67 & 2.89 & 4.92 & 2.90 & 4.94 & 2.72 & 4.63 \\
\hline Mean & & & $3.22^{b}$ & 5.49 & $2.81^{\mathrm{c}}$ & 4.79 & $2.97^{b, c}$ & 5.06 & $2.66^{\mathrm{cd}}$ & 4.53 \\
\hline 308 & 391 & 50 & 3.03 & 7.74 & 2.65 & 6.78 & 2.62 & 6.70 & 2.41 & 6.16 \\
\hline 308 & 391 & 50 & 2.82 & 7.21 & 2.57 & 6.57 & 3.27 & 8.36 & 2.43 & 6.21 \\
\hline 308 & 391 & 50 & 2.83 & 7.24 & 2.62 & 6.70 & 2.94 & 7.52 & 2.74 & 7.01 \\
\hline Mean & & & $2.89^{\mathrm{c}}$ & 7.62 & $2.61^{c, d}$ & 6.67 & $2.94^{b, c}$ & 7.52 & $2.53^{c, d}$ & 6.47 \\
\hline 616 & 1174 & 150 & 4.00 & 3.40 & 3.73 & 3.18 & 3.73 & 3.18 & 3.58 & 3.05 \\
\hline 616 & 1174 & 150 & 3.70 & 3.15 & 3.47 & 2.96 & 3.34 & 2.85 & 3.31 & 2.82 \\
\hline 616 & 1174 & 150 & 3.64 & 3.10 & 3.40 & 3.73 & 3.49 & 2.97 & 3.25 & 2.77 \\
\hline mean & & & $3.78^{a, b}$ & 3.22 & $3.53^{a, b}$ & 3.01 & $3.59^{a, b}$ & 3.06 & $3.38^{\mathrm{b}}$ & 2.88 \\
\hline \multicolumn{11}{|c|}{ (b) } \\
\hline $\begin{array}{c}\text { ETc } \\
\text { Calculated } \\
(\mathrm{mm})\end{array}$ & $\begin{array}{l}\text { Applied } \\
\text { Water } \\
(\mathrm{mm})\end{array}$ & ETc \% & $\begin{array}{c}\text { Yield } \\
\text { PRD-S } \\
\left(\mathrm{Kg} / \mathrm{m}^{2}\right)\end{array}$ & $\begin{array}{c}\text { WUE } \\
\mathrm{Kg} / \mathrm{m}^{3}\end{array}$ & $\begin{array}{c}\text { Yield } \\
\text { PRD-SS } \\
\left(\mathrm{Kg} / \mathrm{m}^{2}\right)\end{array}$ & $\begin{array}{c}\text { WUE } \\
\mathrm{Kg} / \mathrm{m}^{3}\end{array}$ & $\begin{array}{c}\text { Yield } \\
\text { CDI-S } \\
\left(\mathrm{Kg} / \mathrm{m}^{2}\right)\end{array}$ & $\begin{array}{c}\text { WUE } \\
\mathrm{Kg} / \mathrm{m}^{3}\end{array}$ & $\begin{array}{c}\text { Yield } \\
\text { CDI-SS } \\
\left(\mathrm{Kg} / \mathrm{m}^{2}\right)\end{array}$ & $\begin{array}{c}\text { WUE } \\
\mathrm{Kg} / \mathrm{m}^{3}\end{array}$ \\
\hline \multicolumn{11}{|c|}{ Spring Seasons } \\
\hline 485.3 & 616.7 & 100 & 3.18 & 5.16 & 3.05 & 4.95 & 2.89 & 4.69 & 3.27 & 5.31 \\
\hline 485.3 & 616.7 & 100 & 3.18 & 516 & 3.68 & 5.97 & 3.18 & 5.16 & 3.58 & 5.81 \\
\hline 485.3 & 616.7 & 100 & 3.62 & 5.88 & 3.31 & 5.37 & 2.99 & 4.85 & 3.61 & 5.86 \\
\hline Mean & & & $3.33^{a, b}$ & 5.40 & $3.35^{\mathrm{a}, \mathrm{b}}$ & 5.44 & $3.02 \mathrm{~b}$ & 4.90 & $3.48^{\mathrm{a}, \mathrm{b}}$ & 5.65 \\
\hline 364 & 463.2 & 75 & 2.91 & 6.29 & 2.71 & 5.84 & 2.15 & 4.64 & 2.40 & 5.18 \\
\hline 364 & 462.2 & 75 & 2.70 & 5.83 & 2.77 & 5.98 & 2.46 & 5.70 & 2.11 & 4.55 \\
\hline 364 & 462.2 & 75 & 2.83 & 6.11 & 2.63 & 5.68 & 2.21 & 4.77 & 2.23 & 4.81 \\
\hline Mean & & & $2.81^{b, c}$ & 6.07 & $2.70^{b, c}$ & 5.83 & $2.30^{b, c}$ & 4.97 & $2.24^{\mathrm{c}}$ & 4.84 \\
\hline 242.7 & 308.15 & 50 & 2.09 & 6.79 & 2.20 & 7.14 & 1.81 & 5.87 & 1.94 & 6.3 \\
\hline 242.7 & 308.15 & 50 & 1.97 & 6.40 & 2.58 & 8.38 & 1.81 & 5.87 & 1.74 & 5.65 \\
\hline 242.7 & 308.15 & 50 & 1.90 & 6.17 & 2.29 & 7.44 & 1.87 & 6.07 & 1.94 & 6.30 \\
\hline Mean & & & $1.99^{\mathrm{d}}$ & 6.46 & $2.36^{c, d}$ & 7.66 & $1.81^{\mathrm{d}}$ & 5.87 & $1.87^{\mathrm{d}}$ & 6.07 \\
\hline 485.3 & 924.5 & 150 & 3.23 & 3.49 & 3.84 & 4.15 & 3.86 & 4.17 & 4.12 & 4.46 \\
\hline 485.3 & 924.5 & 150 & 3.33 & 3.60 & 3.77 & 4.08 & 3.50 & 3.78 & 3.17 & 3.43 \\
\hline 485.3 & 924.5 & 150 & 2.98 & 3.22 & 3.12 & 3.37 & 3.29 & 3.56 & 3.41 & 3.69 \\
\hline Mean & & & $3.18^{b}$ & 3.44 & $3.38^{a, b}$ & 3.66 & $3.55^{\mathrm{a}, \mathrm{b}}$ & 3.84 & $3.57^{a, b}$ & 3.86 \\
\hline
\end{tabular}




\subsection{SALTMED Data}

The soil water status and salinity distribution and soil nitrogen in the root zone for all irrigation treatments were predicted using the SALTMED model. The data were selected from three irrigation regimes $150 \%, 100 \%$, and $50 \%$ of ETc using the partial root-drying technique. The data represent the prediction values during the four stages of growth of potato crops.

\subsubsection{Water Applied at $150 \%$ of ETc}

\section{Soil Moisture Distribution}

Figure $3 \mathrm{~A}(\mathrm{a}-\mathrm{d})$ shows the distributions of soil moisture $\left(\theta_{v}\right)$ during the four stages of growth under $150 \%$ of ETc. Each appears to have a specific pattern. Soil moisture (SM) contents differ between the growth stages, placement of the dripper, and soil depth. However, SM at first was $0.146,0.166$, and $0.124 \mathrm{~m}^{3} \mathrm{~m}^{-3}$ as an average at depths of $0-25,25-45$, and $45-120 \mathrm{~cm}$, respectively. The highest value was at subsurface $(25-45 \mathrm{~cm})$ under the dripper, whereas at surface $(10) \mathrm{cm}$ was less than $0.1 \mathrm{~m}^{3} \mathrm{~m}^{-3}$ because of the default effect of evaporation. Meanwhile, at the second stage, the soil moisture distribution was semi-elliptical and increased, compared with the first stage, with values of $0.248,0.227,0.195$, and $0.101 \mathrm{~m}^{3} \mathrm{~m}^{-3}$ at soil depths of $0-25,25-45,45-100$, and $100-120 \mathrm{~cm}$. Furthermore, the $\theta_{v}$ in the middle stage was distributed more vertically, where the values of SM were $0.274,0.286,0.206$, and $0.11 \mathrm{~m}^{3} \mathrm{~m}^{-3}$ in depths of $0-25,25-45,45-100$, and $100-120 \mathrm{~cm}$, respectively. The SM content was similar throughout the depths, especially at $50 \mathrm{~cm}$ horizontally from the plant in the horizontal direction, and these values were $0.275,0.263,0.251$, and $0.240 \mathrm{~m}^{3} \mathrm{~m}^{-3}$ in soil depths of $0-25,25-45,45-100$, and $100-120 \mathrm{~cm}$.

\section{Soil Salinity Distribution}

The soil water content predominantly affects the soil salinity distribution presented in Figure $3 \mathrm{~B}(\mathrm{a}-\mathrm{d})$. The salt concentration was relatively high on the surface, especially during the first stage and away from the dripper. On average, salt concentrations were 9.5, 4.2, 3.7, and $2.8 \mathrm{dSm}^{-1}$ in the first stage of growth, and in the second stage, the soil salinity was more obvious at $45 \mathrm{~cm}$ soil depth. On both sides of the line, soil salinity was 10.5 and $15.2 \mathrm{dSm}^{-1}$ at $10 \mathrm{~cm}$ soil depth. However, soil salinity was decreased to $4.9,3.3$, and $2.5 \mathrm{dSm}^{-1}$ at soil depths of $25-45,45-100$, and 100-120 cm, respectively. The soil salt concentration increased under the dripper with growth stages, especially in the surface layer, with values of $2.4,3.3,4.2$, and $2.4 \mathrm{dSm}^{-1}$, whereas during the last stage, it increased to $2.6,2.6,3.55$, and $4.5 \mathrm{dSm}^{-1}$ at soil depths of $0-25,25-45,45-100$, and $100-120 \mathrm{~cm}$, respectively.

\section{Soil Nitrogen}

The SALTMED model showed varying results in predicting the movement of nitrogen by tracking the concentration. However, the higher concentration of nitrogen Figure $3 C(a-d)$ was in the surface layer $(0-15 \mathrm{~cm})$ and ranged between 11.7 and $51.5 \mathrm{mgL}^{-1}$, especially in the first growth stage. In the second growth stage, the results of the prediction showed a high concentration of soil nitrogen of $24 \mathrm{mgL}^{-1}$ at $10-25 \mathrm{~cm}$ soil depth, whereas subsurface layers showed levels of 13.8 and $12.5 \mathrm{mgL}^{-1}$ at $10 \mathrm{~cm}$ and $25-40 \mathrm{~cm}$, respectively. The rest of the soil profile up to $120 \mathrm{~cm}$ showed a concentration of $1.5 \mathrm{mgL}^{-1}$ on average. However, during the third and fourth growth stages, the nitrogen movement was more obvious at a soil depth of $120 \mathrm{~cm}$. The highest concentration was around $19.65 \mathrm{mgL}^{-1}$ at $45-65 \mathrm{~cm}$ and the distribution was heterogeneous on both sides until $75 \mathrm{~cm}$ horizontally. As for the last stage of plant growth, the concentration was different, reaching the lowest levels of $\sim 2.4 \mathrm{mgL}^{-1}$ in the surface layer $(0-15 \mathrm{~cm})$, and the concentration increased vertically where the highest concentration was $20.5 \mathrm{mgL}^{-1}$ at $65-100 \mathrm{~cm}$. 


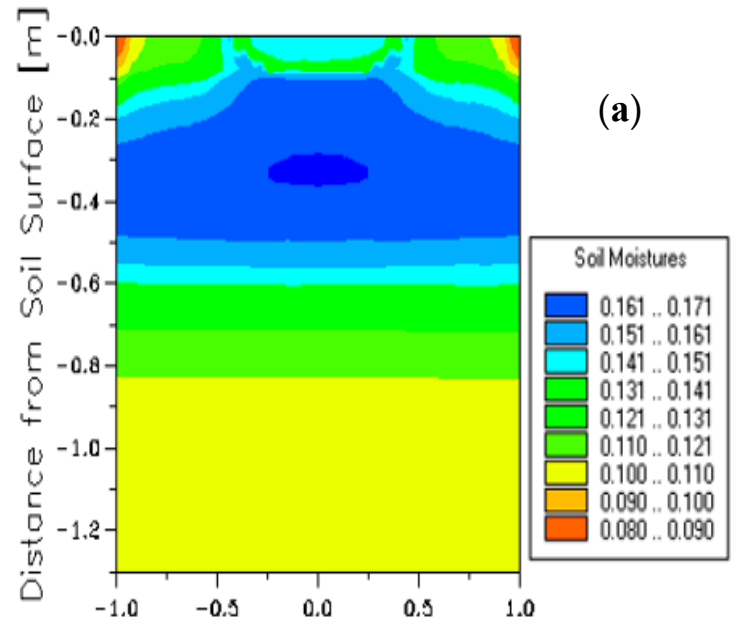

Distance from Irrigation Source $[\mathrm{m}]$

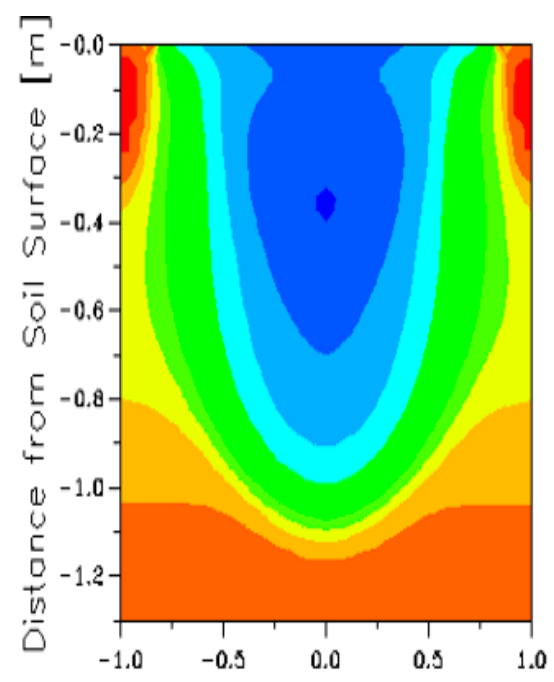

Distance from Irrigation Source $[\mathrm{m}]$

(c)

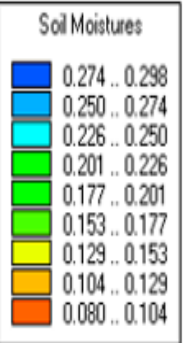

$0.080 . .0$.

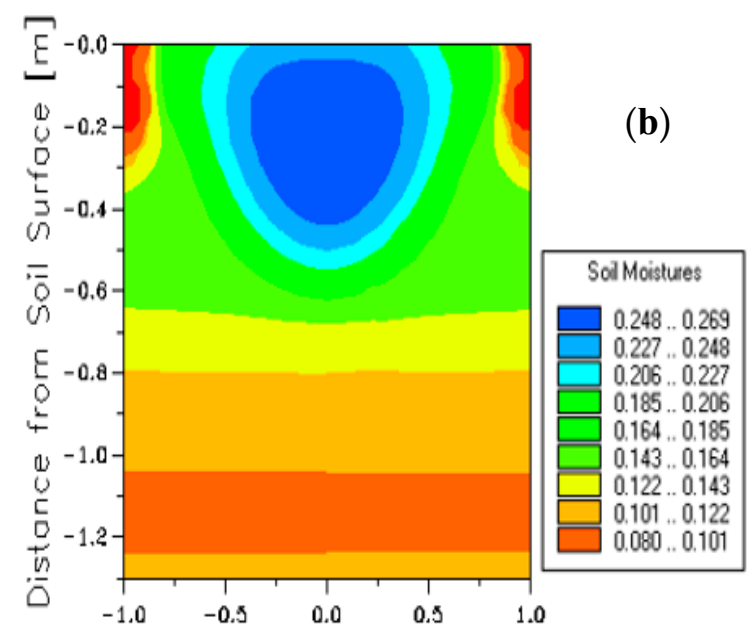

Distance from Irrigation Source $[\mathrm{m}]$

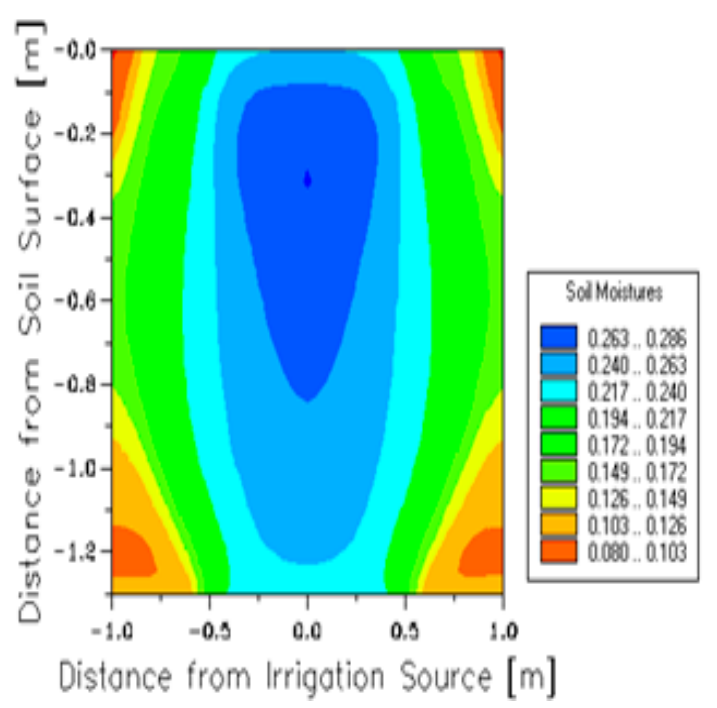

(d)

A

Figure 3. Cont. 


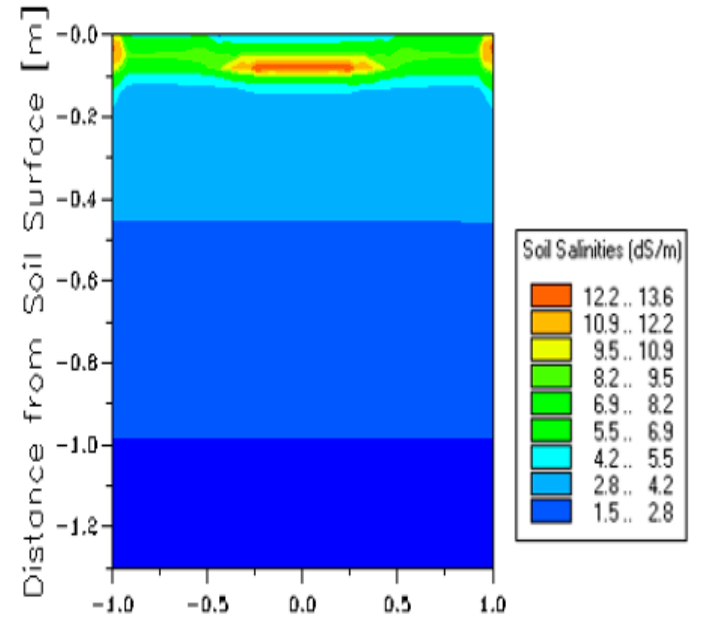

Distance from Irrigation Source [m]

(a)

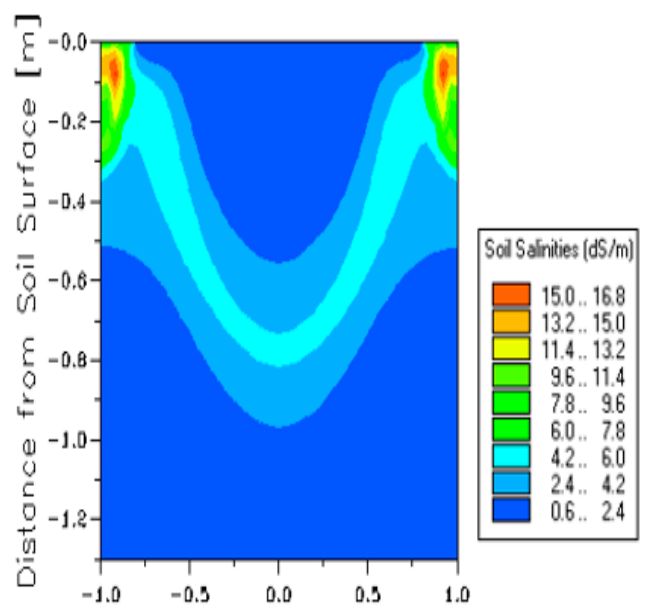

Distance from Irrigation Source $[\mathrm{m}]$

(c)

B

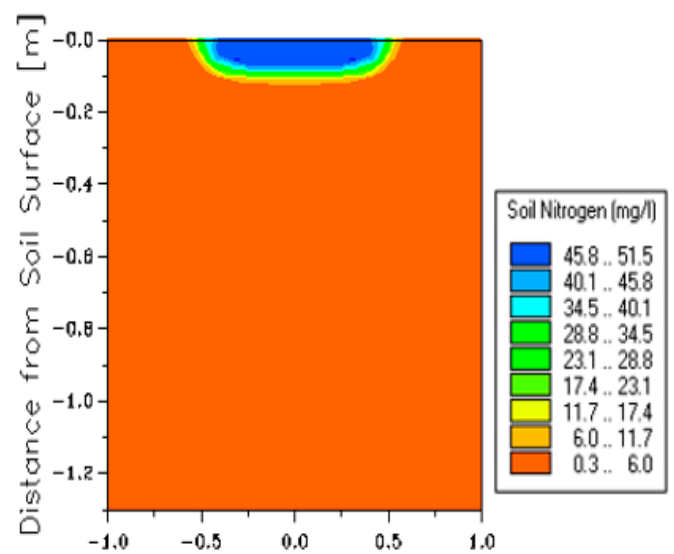

Distance from Irrigation Source [m]

(a)

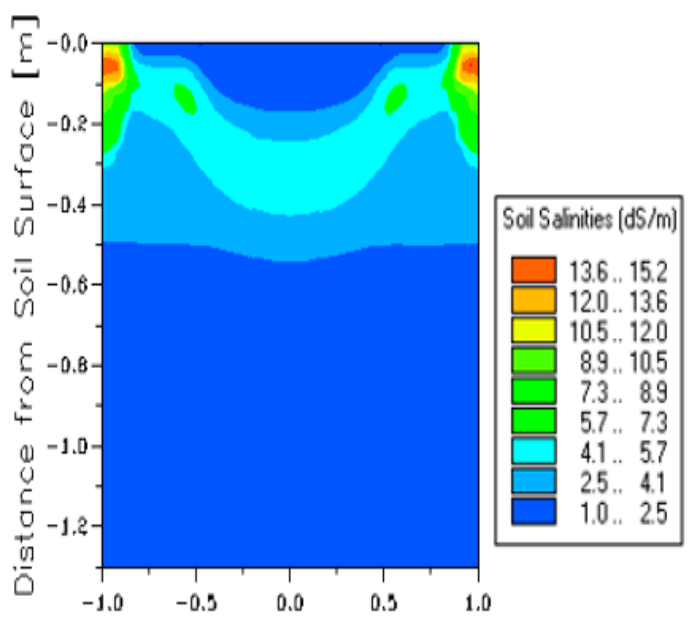

Distance fram Irrigation Source $[\mathrm{m}]$

(b)

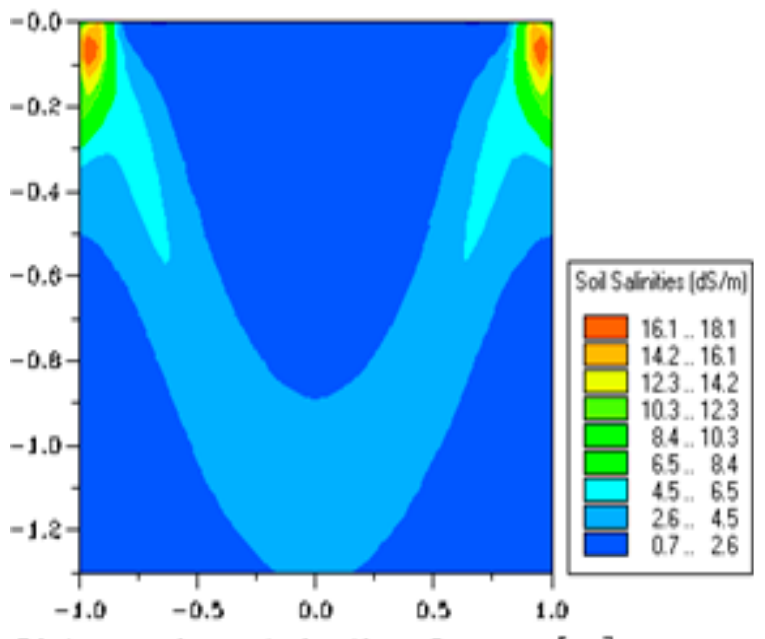

Distance from Irrigation Source [m]

(d)

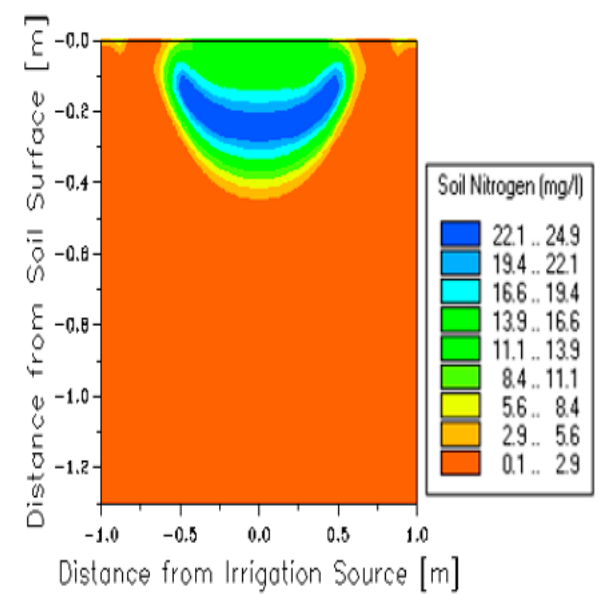

(b)

Figure 3. Cont. 


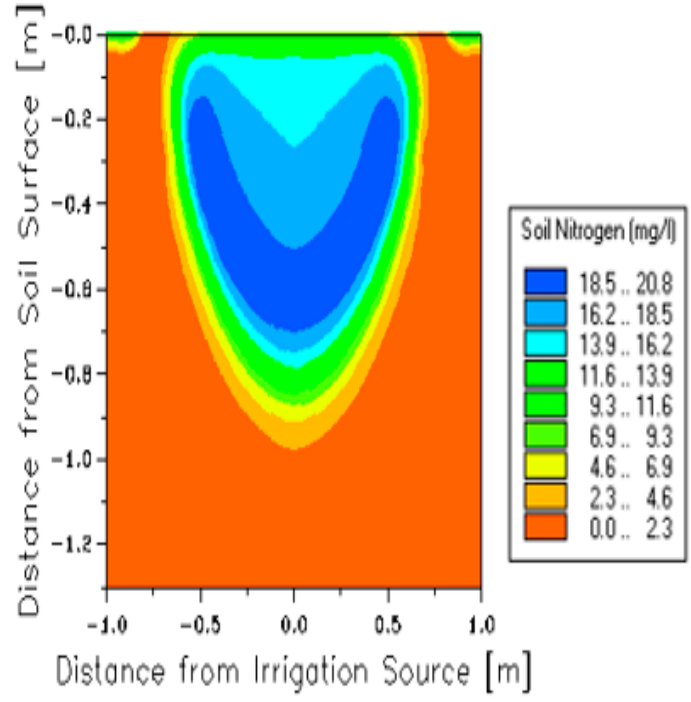

(c)

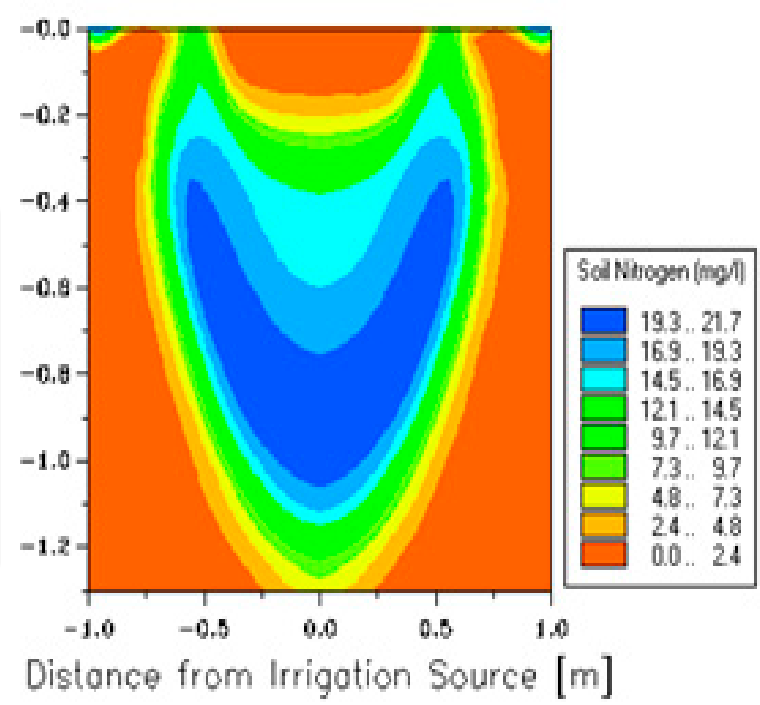

(d)

C

Figure 3. $\mathbf{A}(\mathbf{a}-\mathbf{d})$. The distribution of soil moisture, through stages (a-d) of growth in the soil profile under partial root drying for potato crops at $150 \%$ of ETc, produced by SALTMED model version 2020. B(a-d). The distribution of soil salinity through stages $(\mathbf{a}-\mathbf{d})$ of growth in the soil profile under partial root drying for potato crops at $150 \%$ of ETc, produced by SALTMED model version 2020. $\mathbf{C}(\mathbf{a}-\mathbf{d})$. The distribution of soil nitrogen through stages (a-d) of growth in the soil profile under partial root drying for potato crops at 150\% of ETc, produced by SALTMED model version 2020.

\subsubsection{Water Applied at $100 \%$ of ETc}

\section{Soil Moisture Distribution}

Figure $4 \mathrm{~A}(\mathrm{a}-\mathrm{d})$ show the SM $\left(\theta_{v}\right)$ through all growth stages at $100 \%$ of ETc of water applied. Each has a specific pattern. SM contents were different between growth stages and dripper line placements. SM content $\left(\theta_{v}\right)$ values were $0.162,0.179$, and $0.122 \mathrm{~m}^{3} \mathrm{~m}^{-3}$ as an average at depths of $0-25$, 25-62, and 63-120 cm, respectively. The highest value was at subsurface $(25-62 \mathrm{~cm})$ in the center of the dripper line. In the second stage, the distribution of SM was semi-elliptical from the surface to $57 \mathrm{~cm}$ of soil depth, and higher than that in the first stage, with values of $0.242,0.195,0.127$, and $0.0 .091 \mathrm{~m}^{3} \mathrm{~m}^{-3} \mathrm{at}^{-}$ 0-25, 25-45, 45-100, and 100-120 cm soil depths, respectively. Furthermore, the $\theta_{v}$ in the intermediate stage was more distributed vertically, where the values of $\theta_{v}$ were $0.296,0.270,0.194$, and $0.118 \mathrm{~m}^{3} \mathrm{~m}^{-3}$ at depths of $0-25,25-45,45-100$, and 100-120 cm, respectively. The moisture content was alike on both sides vertically with values of 0.242 and $0.10 \mathrm{~m}^{3} \mathrm{~m}^{-3}$.

\section{Soil Salinity Distribution}

Generally, the salt distribution Figure $4 \mathrm{~B}(\mathrm{a}-\mathrm{d})$ was approximately raised on the surface, specifically during the first stage and away from the plant. The salt concentrations were 9.38, 4.75, 3.7, and $2.8 \mathrm{dSm}^{-1}$ as an average, at soil depths of $0-20,20-45$, and 45-120 cm. In the second stage, the salinity distribution was clear to a soil depth of $43 \mathrm{~cm}$ and both sides of the plant were 3.1 and $5.65 \mathrm{dSm}^{-1}$ at $15 \mathrm{~cm}$ and $15-43 \mathrm{~cm}$ soil depths, respectively. However, salinity during the third and last stages was decreased and more obvious toward the bottom. On the opposite in maximum distance horizontally, the values were 2.7, 5.4, and $1.8 \mathrm{dSm}^{-1}$ for 0-25, 25-60, and 60-120 cm, respectively, in the third stage. Furthermore, the salinity during the last stage of growth was more concentrated horizontally and away from the dripper, and the soil salinity was $\sim 4.5 \mathrm{dSm}^{-1}$ as an average. 


\section{Soil Nitrogen}

Figure $4 \mathrm{C}(\mathrm{a}-\mathrm{d})$ shows a part of the results as predicted concentration and movement of soil nitrogen as $\mathrm{NO}_{3}^{-}$. The results show an increase in the concentration to $33.5 \mathrm{mgL}^{-1}$ in the surface layers $(0-15 \mathrm{~cm})$, compared to the rest $(15-120 \mathrm{~cm})$ of the soil depths, which was $6.4 \mathrm{mgL}^{-1}$ in the first growth stage. In the second growth stage, the results of the modeling showed that the highest concentration of soil nitrogen was $26 \mathrm{mgL}^{-1}$ at a soil depth of $15-25 \mathrm{~cm}$, contrary to the surface and subsurface layers of 16.3 and $13.06 \mathrm{mgL}^{-1}$, respectively. Furthermore, during the third and fourth growth stages, the nitrogen movement was more obvious to the bottom of the soil profile $(120 \mathrm{~cm})$. The highest concentration of $22.2 \mathrm{mgL}^{-1}$ at $20-45 \mathrm{~cm}$ and the distribution was heterogeneous on both sides until $80 \mathrm{~cm}$ horizontally. As for the last stage of plant growth, the concentration was different, reaching the lowest levels of $\sim 4.6 \mathrm{mgL}^{-1}$ in the surface layer $(0-10 \mathrm{~cm})$, and the concentration differed vertically, where the highest concentration was $18.3 \mathrm{mgL}^{-1}$ at a depth of $10-110 \mathrm{~cm}$.

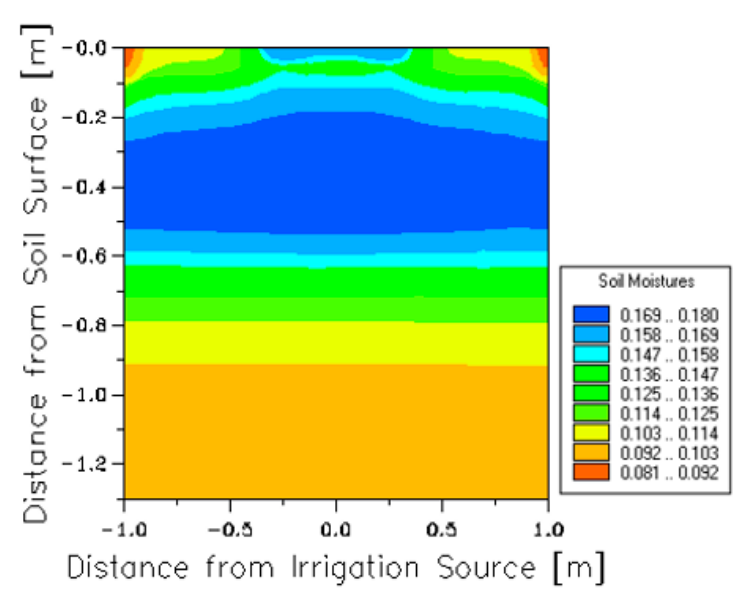

(a)

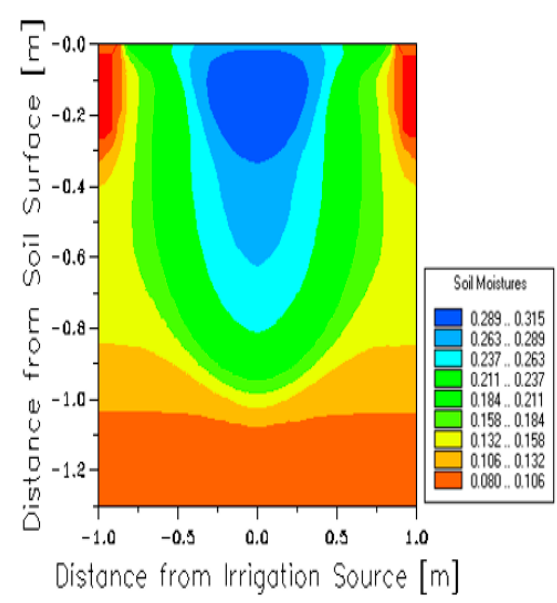

(c)

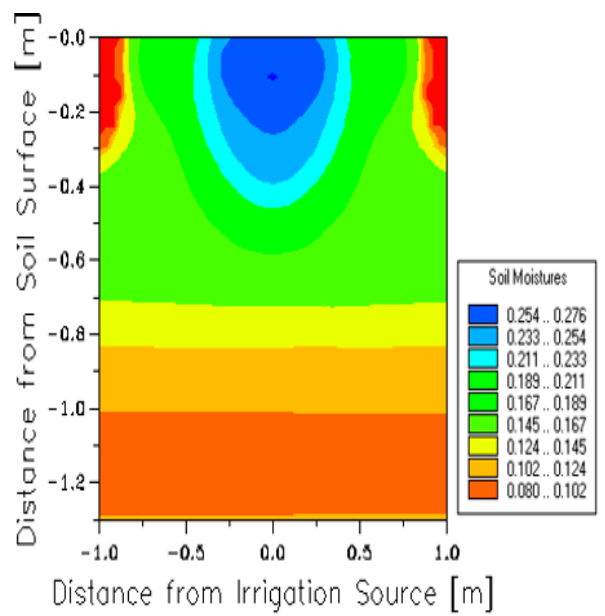

(b)

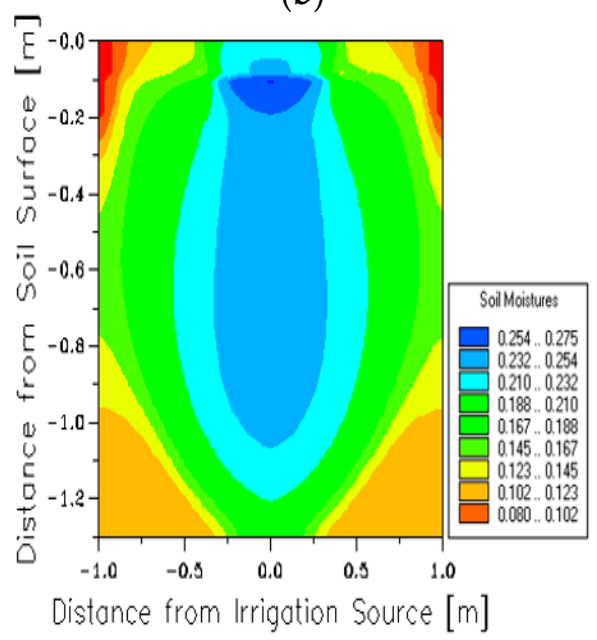

(d)

A

Figure 4. Cont. 


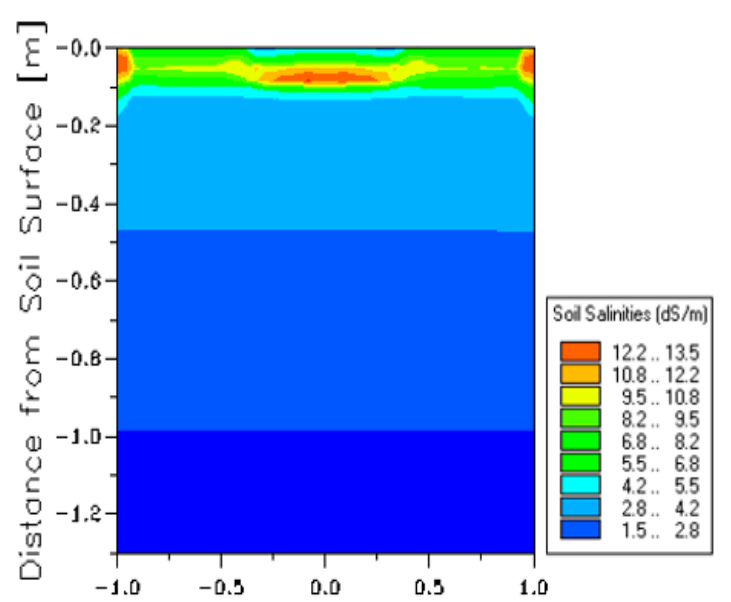

Distance from Irrigation Source [m]

(a)

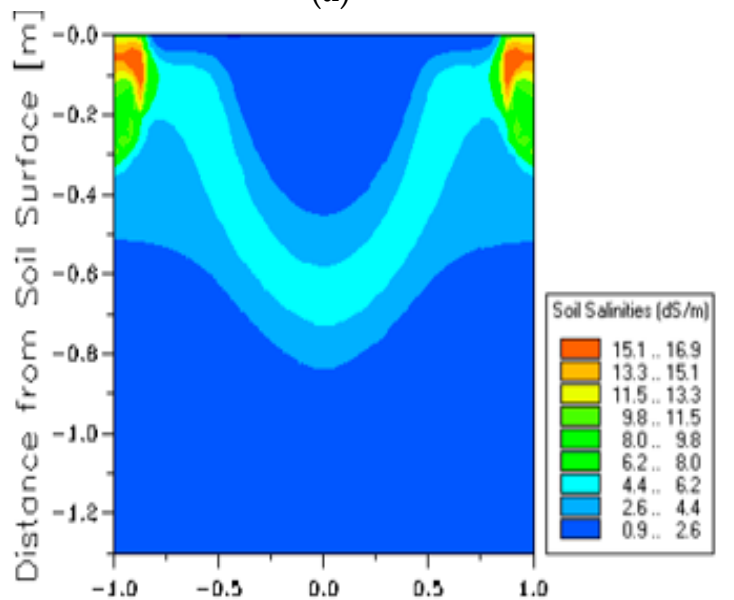

Distance from Irrigation Source $[\mathrm{m}]$

(c)

\section{B}

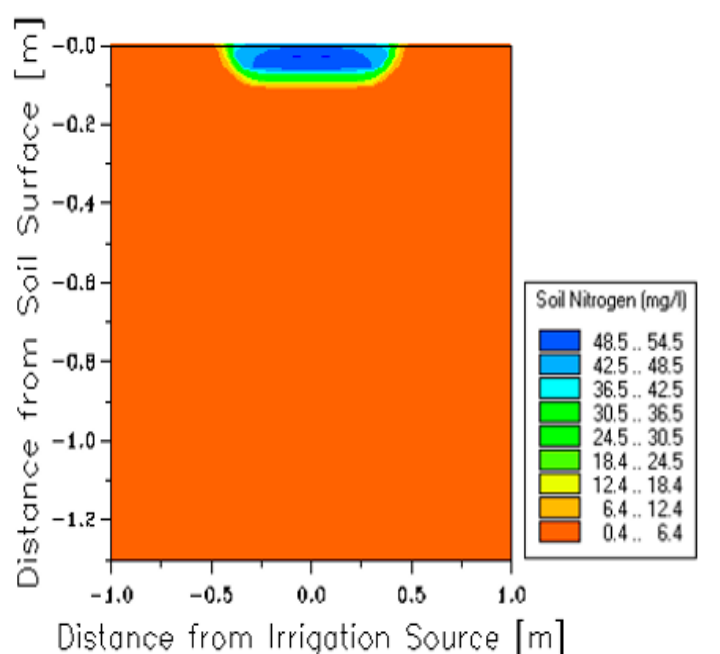

(a)

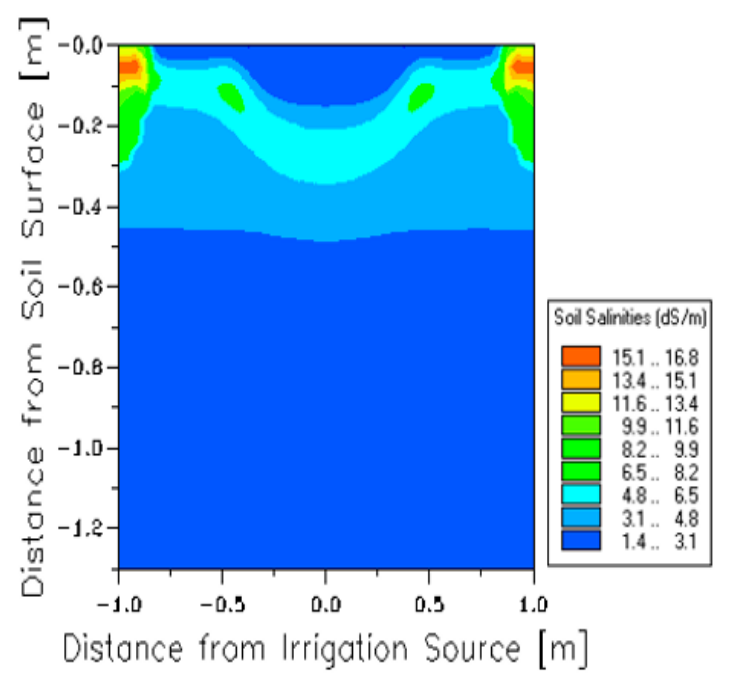

(b)

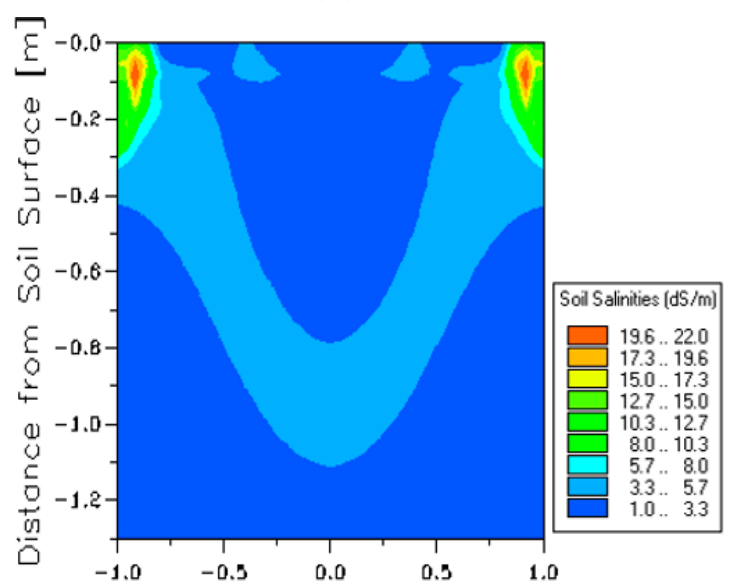

Distance from Irrigation Source $[\mathrm{m}]$

(d)

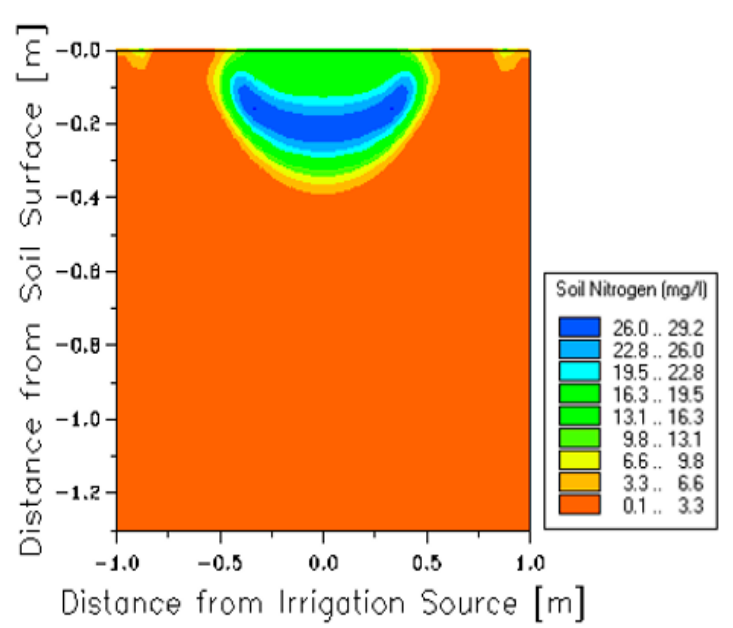

(b)

Figure 4. Cont. 


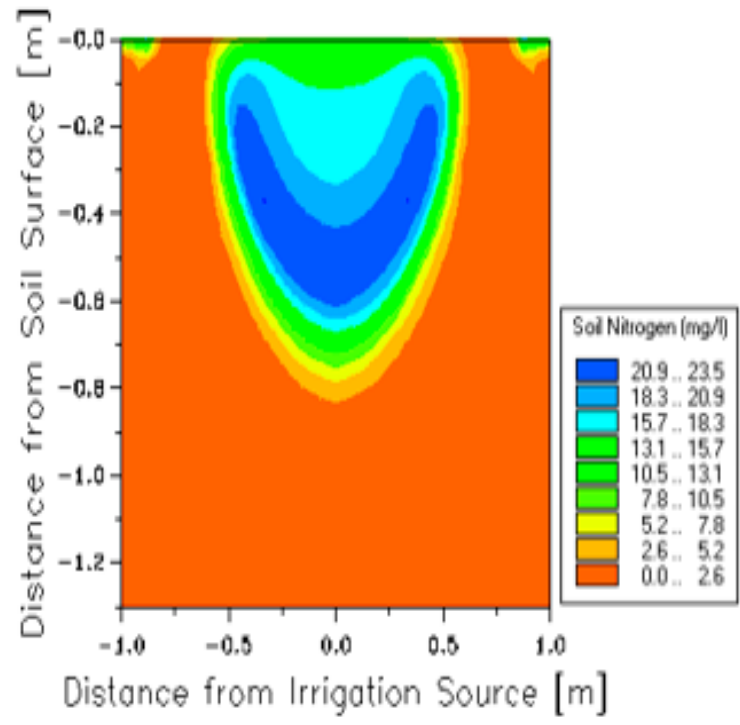

(c)

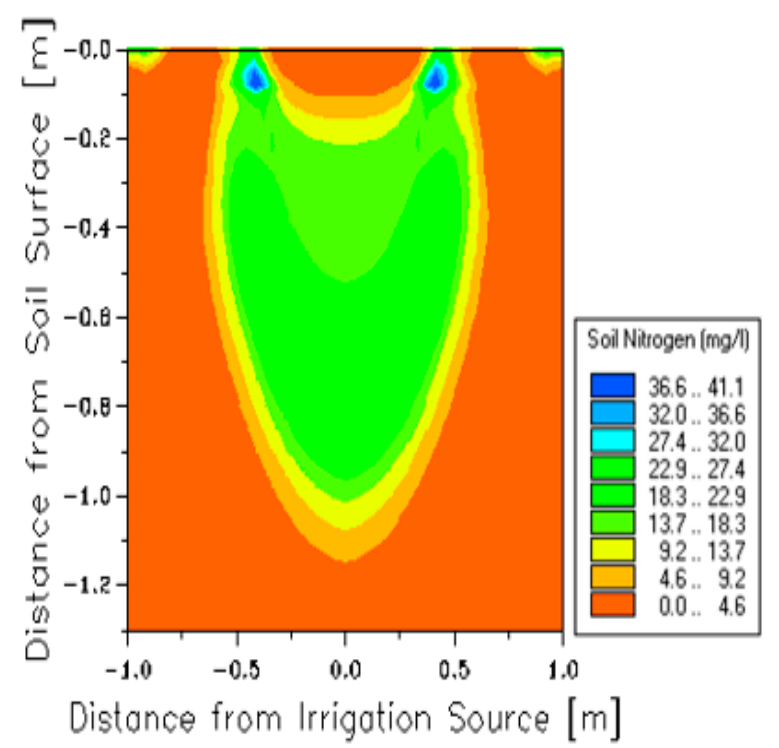

(d)

C

Figure 4. A(a-d). The distribution soil moisture through stages (a-d) of growth in the soil profile under partial root drying for potato crops at $100 \%$ of ETc, produced by SALTMED model version 2020. B(a-d). The distribution of soil salinity through stages (a-d) of growth in the soil profile under partial root drying for potato crops at 100\% of ETc, produced by SALTMED model version 2020. $\mathbf{C}(\mathbf{a}-\mathbf{d})$. The distribution of soil nitrogen through stages (a-d) of growth in the soil profile under partial root drying for potato crops at 100\% of ETc, produced by SALTMED model version 2020.

\subsubsection{Water Applied at $50 \%$ of ETc}

Soil Moisture Distribution

Figure $5 \mathrm{~A}(\mathrm{a}-\mathrm{d})$ show different SM distribution patterns under severe irrigation levels of $50 \%$ of ETc. However, the $\theta_{v}$ values as an average of the $0-25,25-62,63-100$, and 100-120 cm soil depths were $0.162,0.18,0.122$, and $0.104 \mathrm{~m}^{3} \mathrm{~m}^{-3}$, respectively. The highest moisture content was at $25-63 \mathrm{~cm}$. In the second stage of growth, the moisture distribution was identical around the plant until $40 \mathrm{~cm}$ soil depth. The $\theta_{v}$ was increased by $49.38 \%$ in the surface layer compared to the previous stage to $0.242,0.195$, and $0.127 \mathrm{~m}^{3} \mathrm{~m}^{-3}$ for $0-25,25-85$, and $86-120 \mathrm{~cm}$, respectively. However, the $\theta_{v}$ during the third growth stage was $0.296,0.270,0.194$, and $0.118 \mathrm{~m}^{3} \mathrm{~m}^{-3}$ for $0-25,25-60,61-100$, and up to $120 \mathrm{~cm}$, respectively. The soil moisture content was $0.242 \mathrm{~m}^{3} \mathrm{~m}^{-3}$ as an average and was similar along the soil profile, increasing from the top layer to subsurface layers.

\section{Soil Salinity Distribution}

Figure $5 \mathrm{~B}(\mathrm{a}-\mathrm{d})$ show the soil salinity distribution, showing the highest percentage accumulation of salt in the surface soil layer as $9.38 \mathrm{dSm}^{-1}$ as an average at $0-20 \mathrm{~cm}$ of soil depth during the first stage of growth, whereas the other soil profile salinity was 4.75 and $2.8 \mathrm{dSm}^{-1}$ for $20-45$ and $45-120 \mathrm{~cm}$, respectively. In the second stage, the highest salinity concentration predicted was $5.65 \mathrm{dSm}^{-1}$ at $15-43 \mathrm{~cm}$ soil depth, compared to the surface layer $(0-15 \mathrm{~cm})$ at $3.1 \mathrm{dSm}^{-1}$ and the subsurface layer $(43-120 \mathrm{~cm})$ at $2.25 \mathrm{dSm}^{-1}$. The salinity was higher away from the plant horizontally and reached $16.05 \mathrm{dSm}^{-1}$ at $100 \mathrm{~cm}$. Furthermore, during the third and last stages of growth, the salinity concentration moved downward, concurring with the decrease in the surface layer, irrespective of concentrations horizontally. The salinity values were $2.7,5.4$, and $1.8 \mathrm{dSm}^{-1}$ for $0-25,25-60$, and 60-120 cm depths during the third stage, whereas in the last stage, the value was $4.2 \mathrm{dSm}^{-1} \mathrm{as}^{-1}$ an average. 


\section{Soil Nitrogen}

The decrease in irrigation to 50\% ETc affected the nitrogen concentration using the SALTMED model prediction. Figure $5 \mathrm{C}(\mathrm{a}-\mathrm{d})$ show the prediction concentration of $\mathrm{NO}_{3}{ }^{-}$and the average value was $32.85 \mathrm{mgL}^{-1}$ for the first stage, whereas the concentration was decreased with depth. However, as the growth days advanced, the high concentrations increased with depth to $18.63,15.88$, and $20.08 \mathrm{mgL}^{-1}$ for 15-25, 15-60, and 15-85 cm soil depth in the second, third, and last stage of growth, respectively.

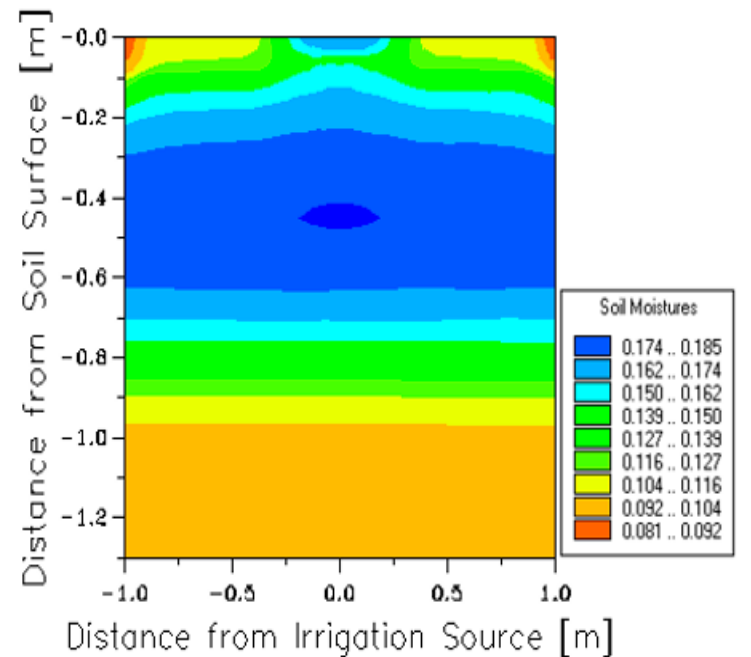

(a)

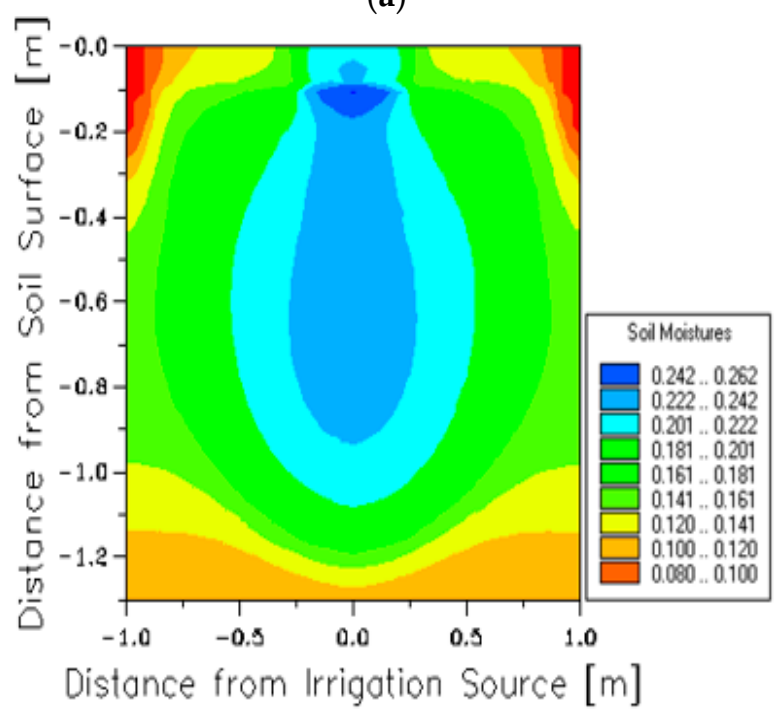

(c)

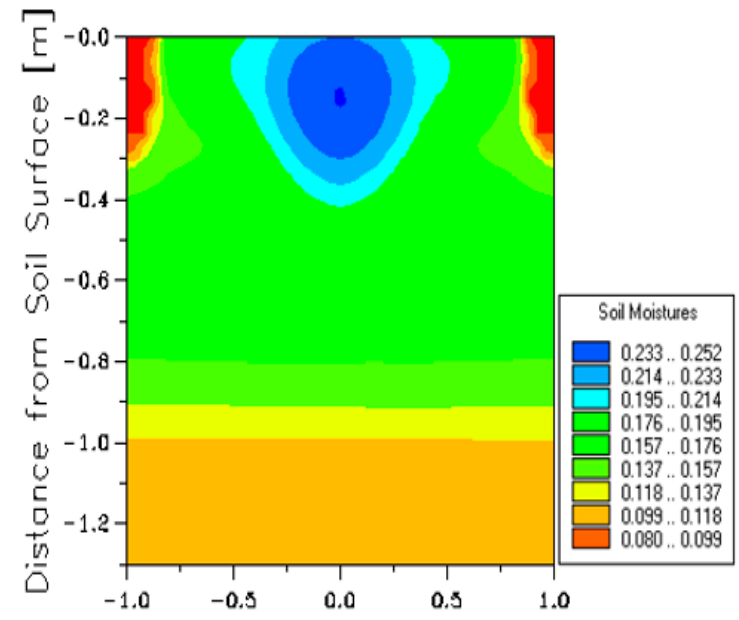

Distance from Irrigation Source $[\mathrm{m}]$

(b)

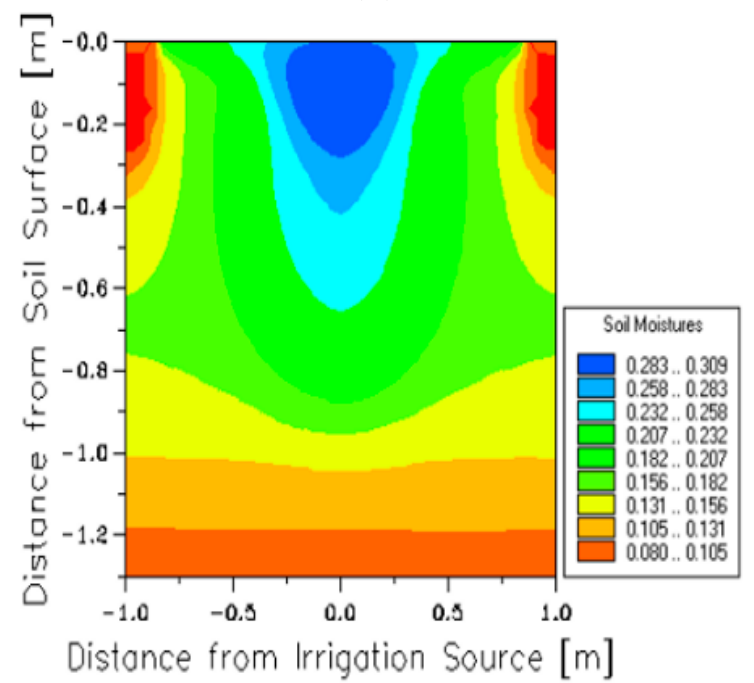

(d)

A

Figure 5. Cont. 


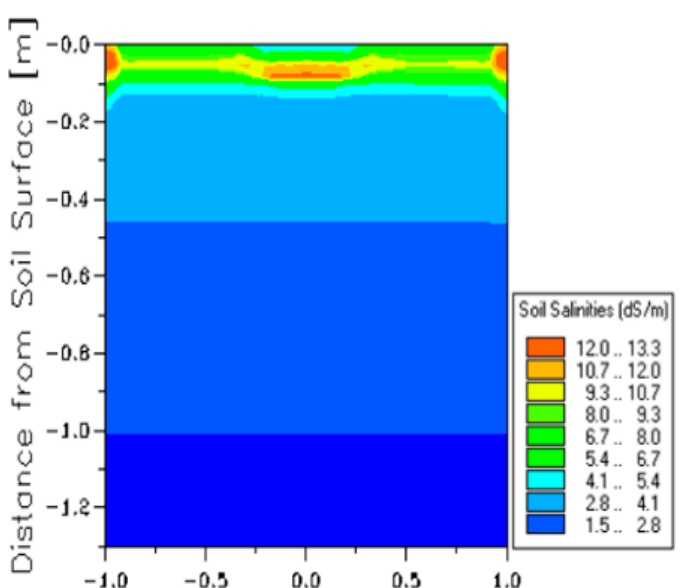

Distance from Irrigation Source $[\mathrm{m}]$

(a)

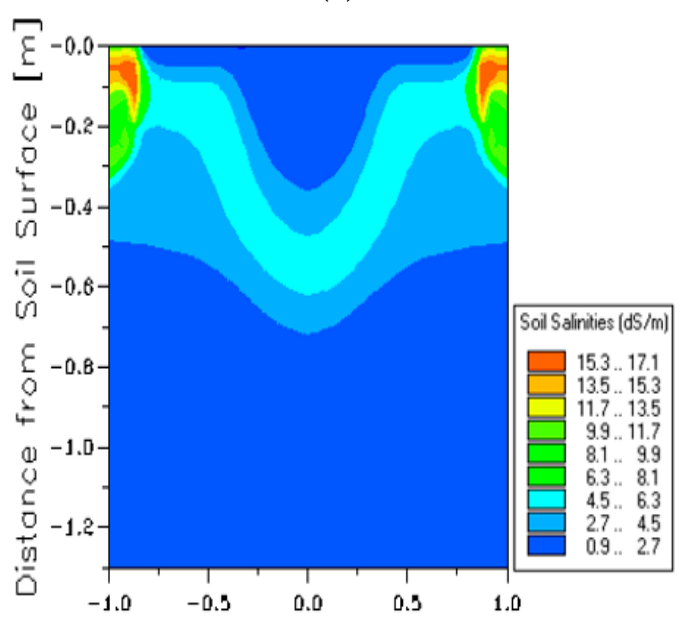

Distance from Irrigation Source [m]

(c)

B

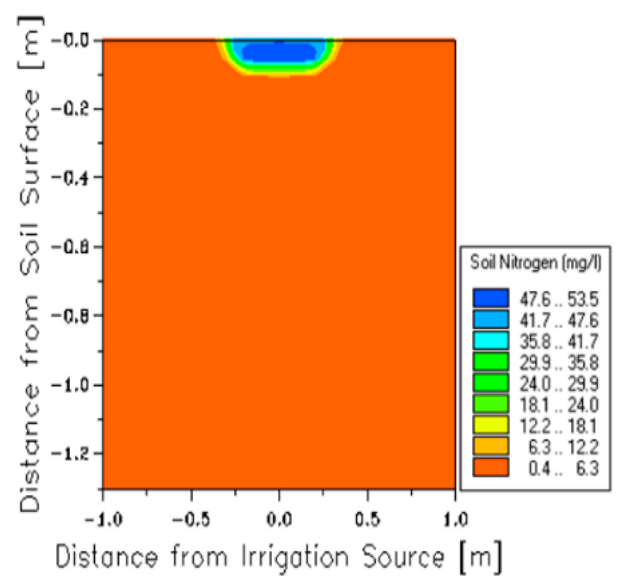

(a)

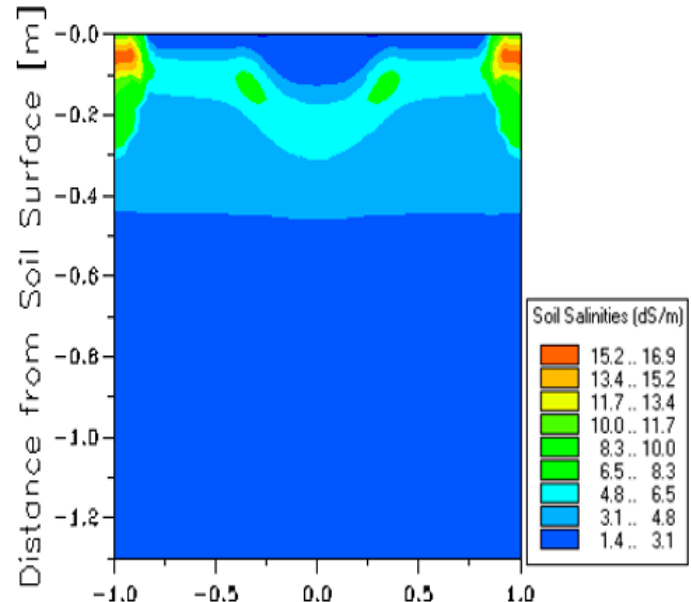

Distance from Irrigation Source $[\mathrm{m}]$

(b)

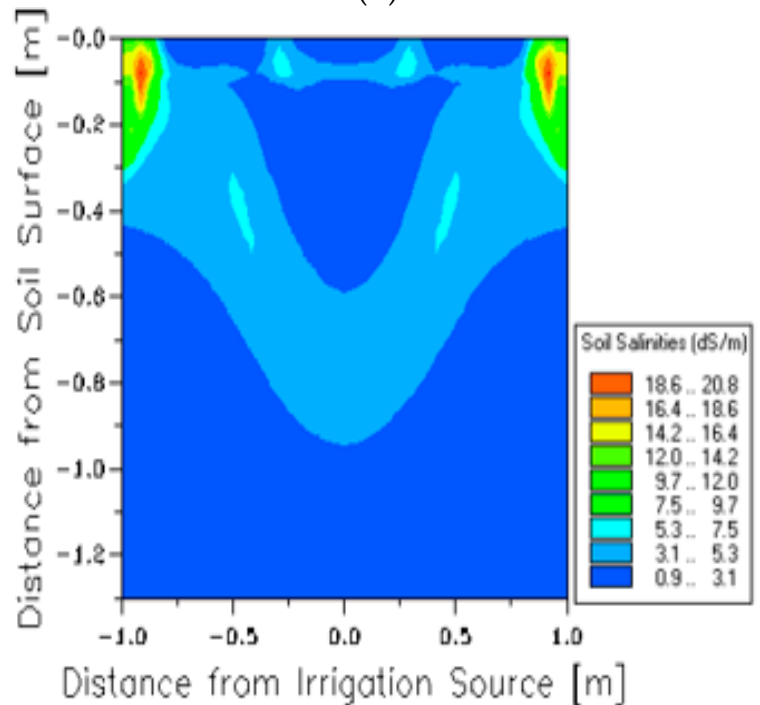

(d)

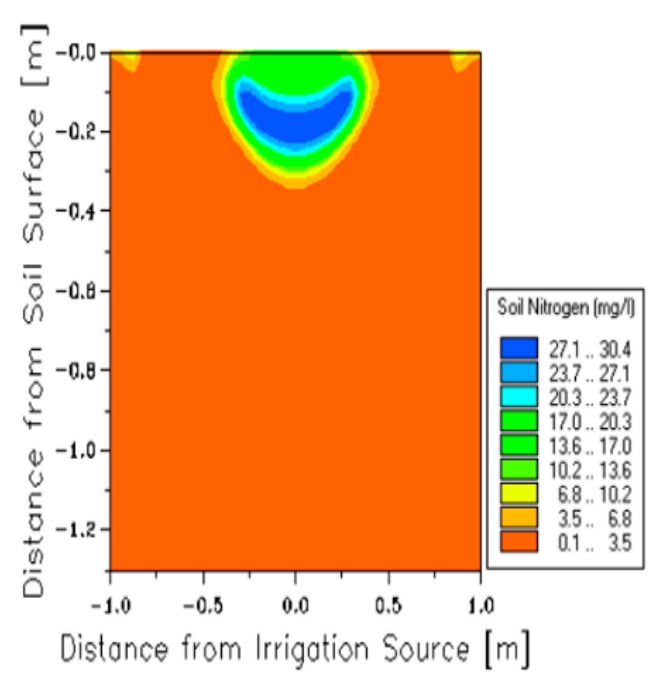

(b)

Figure 5. Cont. 


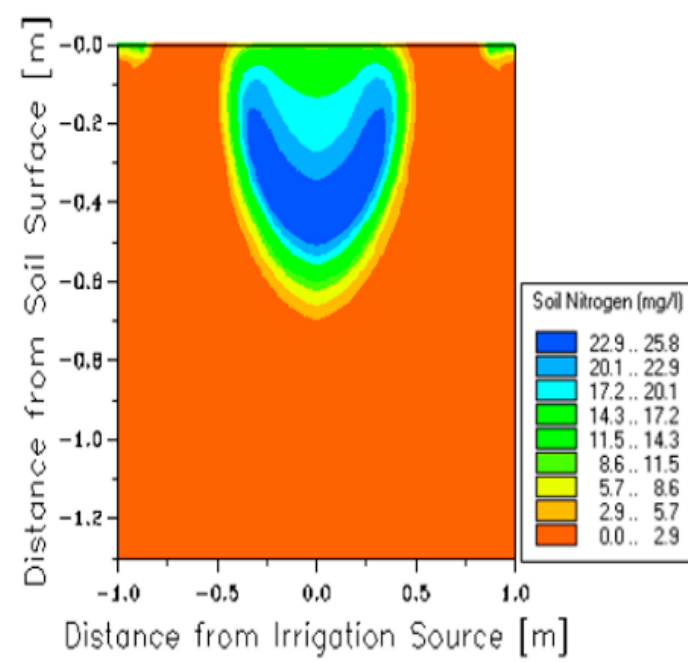

(c)

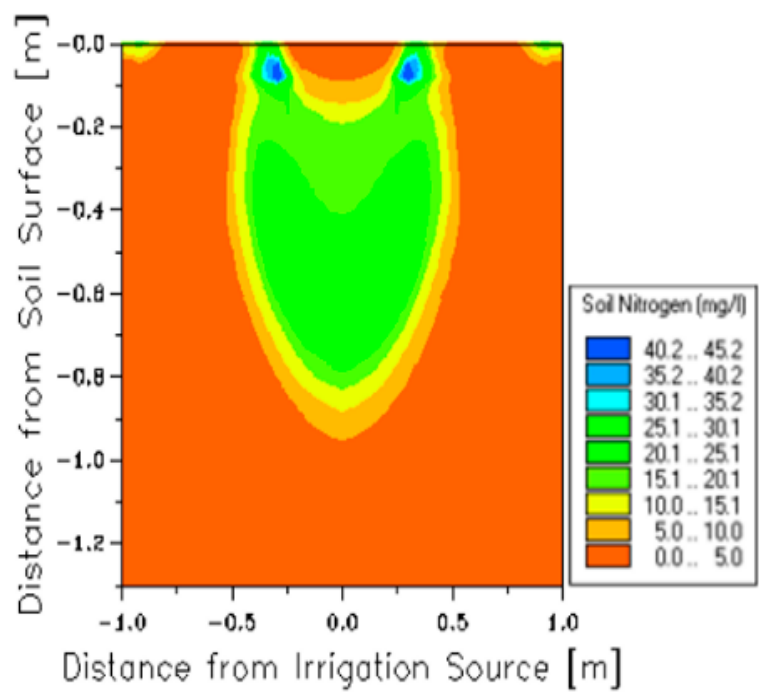

(d)

C

Figure 5. A(a-d). The distribution of soil moisture through stages (a-d) of growth in the soil profile under partial root drying for potato crops at 50\% of ETc, produced by SALTMED model version 2020. B $(\mathbf{a}-\mathbf{d})$. The distribution soil salinity through stages $(\mathbf{a}-\mathbf{d})$ of growth in the soil profile under partial root drying for potato crops at $50 \%$ of ETc, produced by SALTMED model version 2020 . $\mathbf{C}(\mathbf{a}-\mathbf{d})$. The distribution of soil nitrogen through all stages $(\mathbf{a}-\mathbf{d})$ of growth in the soil profile under partial root drying for potato crops at $50 \%$ of ETc, produced by SALTMED model version 2020.

The Yield

The results in Table 7 show statistical indicators of yield, showing a good correlation between the observed and simulated production of potatoes with PRD, whereas the yield decreased in the predicted compared to the observed data, especially with high deficit irrigation at $50 \%$ of ETc. Table 8 compares the observed and simulated yield of potatoes and relative errors (RE) for different water irrigation levels. The RE values ranged from 6.51 to $19.63 \%$. The results of the model are authoritative to simulate potato yield in arid conditions.

Table 7. Statistical indicators of soil moisture content, soil salinity, and three irrigation regimes.

\begin{tabular}{cccccccc}
\hline Treatment & MAD & MSE & RSME & MAPE & MRE & CRM & $\mathbf{R}^{\mathbf{2}}$ \\
\hline SM & 0.01056 & 0.00016 & 0.01278 & 5.75750 & 0.00011 & -0.00061 & 0.94561 \\
SS & 4.50000 & 22.97829 & 4.79357 & 107.52623 & 4.50000 & -0.79662 & 0.93944 \\
150 & 3.16551 & 10.69341 & 3.27008 & 8.42691 & -3.16551 & 0.08370 & 0.88020 \\
100 & 5.26852 & 27.77429 & 5.27013 & 15.40583 & -5.26852 & 0.15374 & 0.99982 \\
50 & 3.86148 & 16.73179 & 4.09045 & 13.50786 & -3.86148 & 0.13362 & 0.90908 \\
\hline
\end{tabular}

Table 8. Observed versus simulated total potato yield.

\begin{tabular}{cccc}
\hline \% of ETc & Observed, $\mathbf{t} \mathbf{h a}^{\mathbf{- 1}}$ & Simulated, $\mathbf{t} \mathbf{h a}^{-\mathbf{1}}$ & $\mathbf{R E} \%$ \\
\hline \multirow{2}{*}{150} & 40.03 & 37.25 & 6.95 \\
& 37.00 & 34.59 & 6.51 \\
\multirow{3}{*}{100} & 36.43 & 32.12 & 11.82 \\
& 31.72 & 26.60 & 16.15 \\
& 34.44 & 29.20 & 15.23 \\
50 & 36.64 & 31.20 & 14.84 \\
& 30.25 & 28.02 & 7.37 \\
& 28.19 & 22.66 & 19.63 \\
& 28.25 & 24.43 & 13.52 \\
\hline
\end{tabular}




\section{Discussion}

\subsection{Crop Water Requirements}

The results in Table 5 are relatively consistent with what was reported by Van der Zaag (1991) that the average daily sprinkler irrigation of potato crops in the fall season in the Kingdom during the months of November, December, and January is $12 \mathrm{~mm}$ every 3 days at a rate of $4 \mathrm{~mm} /$ day and for the spring season during the months of February, March and April is 5 and 10 and $12 \mathrm{~mm} /$ day. These values are also in line with what was mentioned by Al-Omran et al. (2019) [25] that the water requirements for irrigation of potatoes in the Riyadh region during the fall and spring season were 6207 and $7536 \mathrm{~m}^{3} /$ ha/season (i.e., 620.7 and $753.6 \mathrm{~mm}$ ), respectively. In the case of drip irrigation with saline water the value was $1000 \mathrm{ppm}$, which is also within the FAO estimate of 500-700 mm [26].

\subsection{The Effect of Water Application on Yield during the Spring Season}

It was observed that the decrease in yield as a result of a $50 \%$ reduction in irrigation in the surface drip irrigation treatment was less than the decrease in subsurface irrigation by almost twice as much in both PRD and DI cases during this season, contrary to what had been expected. By increasing the irrigation percentage to $150 \%$, the yield of the treatments did not increase by that percentage, as the percentage of increase was $11.3 \%, 4.0 \%$, and $5.5 \%$ for the PRD-S, PRD-SS, and CFI-S treatments, respectively, while this increase in irrigation has negatively affected the yield of potatoes in the subsurface irrigation treatment (CFI-SS).

The increase in irrigation rates has led to a decrease in the water use efficiency (WUE) (Table 6a,b). The results showed that WUE by PRD system is higher than conventional full irrigation (CFI) or conventional deficit irrigation (CDI) in all cases. The results indicated that the WUE decreases with increasing levels of irrigation water, as it ranged between 3.10 and $7.74 \mathrm{kgm}^{-3}, 2.96$, and $6.70 \mathrm{kgm}^{-3}$, for surface irrigation PRD and CDI, respectively, when the amounts of irrigation water varied from $308 \mathrm{~mm}$ to $1174 \mathrm{~mm}$, respectively, while PRD-SS and CDI-SS irrigation were $2.77-8.38 \mathrm{kgm}^{-3}$, and $2.77-7.01 \mathrm{Kgm}^{-3}$, respectively for the same amounts of irrigation water. The results indicated that in the spring season, the subsurface drip irrigation method was the least efficient in using water, followed by the conventional surface irrigation. The results showed that the water yield was highest when applying the PRD-S system, followed by PRD-SS.

\subsection{The Effect of Water Application on Yield during the Fall Season}

The yield of the CFI-S drip irrigation treatment of $100 \%$ was taken as a standard basis for comparison of all potato harvest results for all treatments. Results of statistical analysis using $\mathrm{LSD}_{05}$. The results showed that-and unlike the spring season — the yield of potatoes under surface irrigation method gave higher yield than the other treatments with rates of $10.6 \%$ and $15.3 \%$ with the PRD-SS and CDI-SS, respectively, than the conventional surface CDI-S (Table 6b). However, with a $75 \%$ irrigation treatment, the decrease in yield in CFI-S was approximately 24.1 and $25.5 \%$ for the CDI-S and CDI-SS irrigation system, respectively, while the decrease in PRD system was 6.7 and $10.4 \%$ for the PRD-S and PRD-SS irrigation system, respectively. With the irrigation level reduced to $50 \%$ the percentage decrease in yield was 34.1, 22.1, 39.5, and 37.8\% for the irrigation treatments PRD-S, PRD-SS, CDI-S and CDI-SS, respectively. It was observed in this study that the percentage of decrease in PRD-SS was the lowest, in contrast to what was observed in the spring season. With an increase in the irrigation ratio to $150 \%$, there was an increase in yield of $18.6,17.8,12.2$, and $5.3 \%$ for the PRD-S, PRD-SS, CFI-S and CFI-SS treatments, respectively. However, this increase does not correspond to the increase in irrigation. The results of the fall season did not differ from the spring season, as the water yield was the highest when the PRD-S system was applied with surface irrigation, followed by subsurface irrigation with the same system. Table $6 \mathrm{~b}$ illustrated by the statistical analysis, the decrease in water use efficiency (WUE) is more rapid with the increase in the added water when applying the conventional subsurface irrigation system. 


\subsection{SALTMED}

After the successful (calibration and validation) processes of SALTMED, it was used for other irrigation treatment data. The agreement between the observed and simulated data for SM and soil salinity through all soil depths $(0-120 \mathrm{~cm})$ is shown in Figure $6 \mathrm{a}, \mathrm{b}$, and statistical indicators are shown in Table 7. The data show a slight difference existed between the observed and simulated data for moisture and salinity. The results showed that the value of RSME was 0.0128 for $100 \%$ of ETc, and $\mathrm{R}^{2}$ was 0.95 for soil moisture for soil depths of $0-120 \mathrm{~cm}$, and CRM was -0.00061 overestimated. However, statistical indicators of soil salinity were $4.78,-0.79662$, and 0.94 for RSME, CRM, and $\mathrm{R}^{2}$, respectively. Here, the CRM values were negative, indicating that the model overestimated for moisture and salinity. The surface layer of soil showed less moisture, especially at $50 \%$ of ETc. The advanced growth stage could be affected by weather fluctuation, the root of the plant, and most dynamic changes, such as soil evaporation and agricultural processes. Furthermore, in high irrigation regimes at $150 \%$ of ETc, the soil moisture was high in depths of 100-120 cm compared with other irrigation levels because of the high added water and texture of sand soil characterizing a high infiltration rate. However, the salt concentration percentage was high in the surface layers far from the source of irrigation because of high evaporation [8,27-29]. Generally, the relationship between observed and simulated values under all irrigation regimes with the PRD technique showed a high correlation, which is a good indicator of the SALTMED model in predicted soil moisture and salinity distribution.

The model was good for the predicted yield of potatoes under all irrigation regimes after calibration processes. Figure $7 \mathrm{a}-\mathrm{c}$ shows the correlation of the model for yield for $150 \%, 100 \%$, and $50 \%$ of ETc, respectively. The efficiency of the model in predicting yield was measured using the statistical indicators presented in Table 7. The $\mathrm{R}^{2}$ values were $0.88,0.99$, and 0.90, and RSME were 3.27, 5.27, and 4.09 for $150 \%, 100 \%$, and $50 \%$ of ETc, respectively. The CRM values were 0.08 to 0.15 , which was slightly underestimated. The RE values in Table 5 between the observed and simulated data ranged from $6.51 \%$ to $19.63 \%$. Karandish and Simunek (2019) [30] reported that RE values ranged from 3.5-8.3\% in 2010 and 3.6-7.9\% in 2011. Hassanli et al. (2016) [31] reported that RE values ranged from $0.9-24.7 \%$ with corn crop yield under different quality and saline treatments. Ragab et al. (2005) [1] reported RE values in the range of $0-21.5 \%$ as an average of $5.7 \%$, and Razzaghi et al. (2011) [32] highlighted that RE was $0.8-2.2 \%$ as an average of $1.5 \%$ for quinoa crop. The data indicated that the SALTMED model perfectly estimated potato yield. These results agree with many other studies $[8,9,18-20,33,34]$.

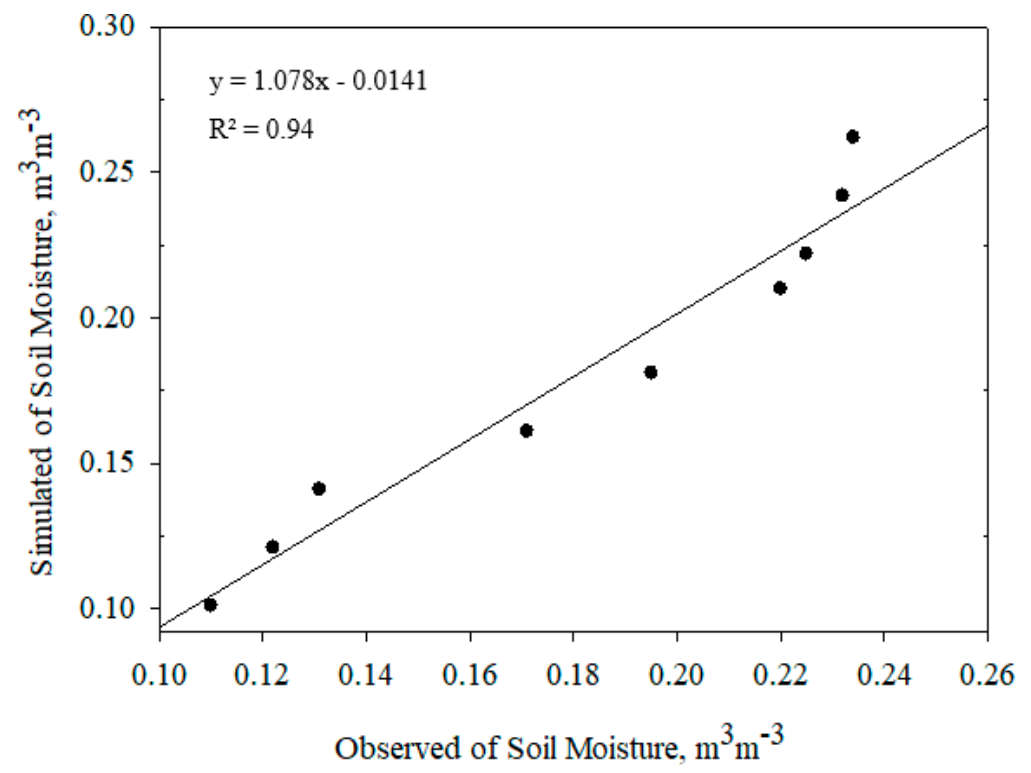

(a)

Figure 6. Cont. 


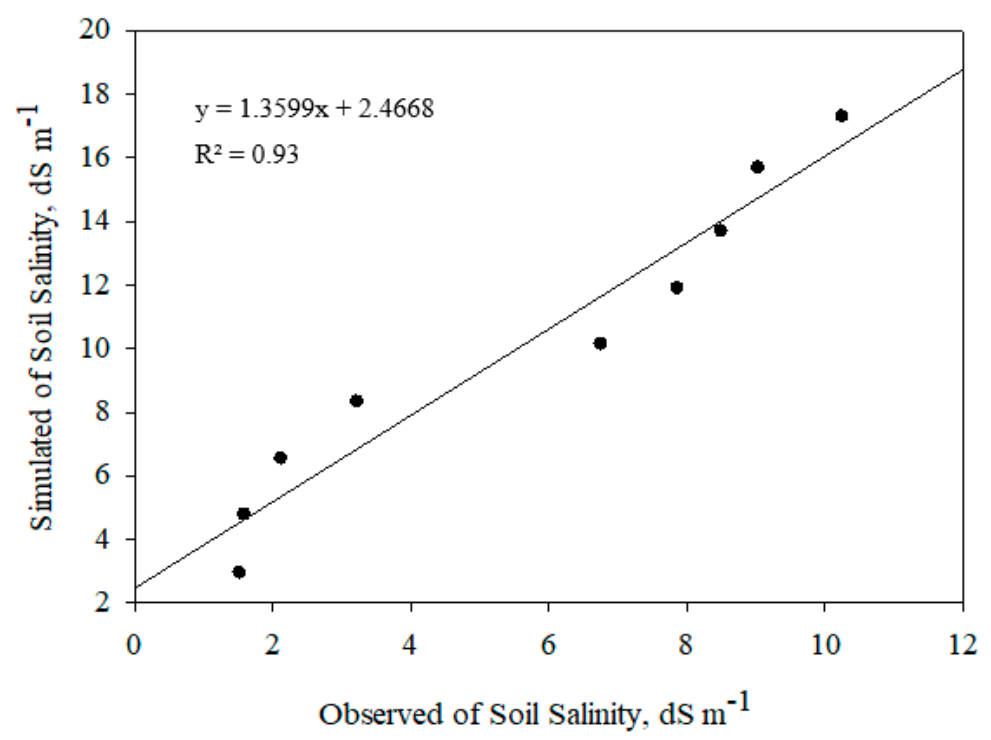

(b)

Figure 6. Correlation between observed and simulated data for (a) soil moisture and (b) soil salinity.

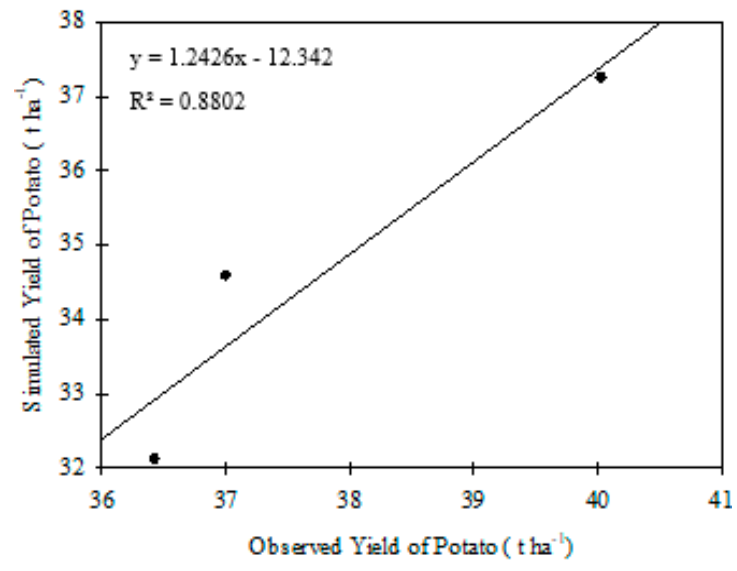

(a)

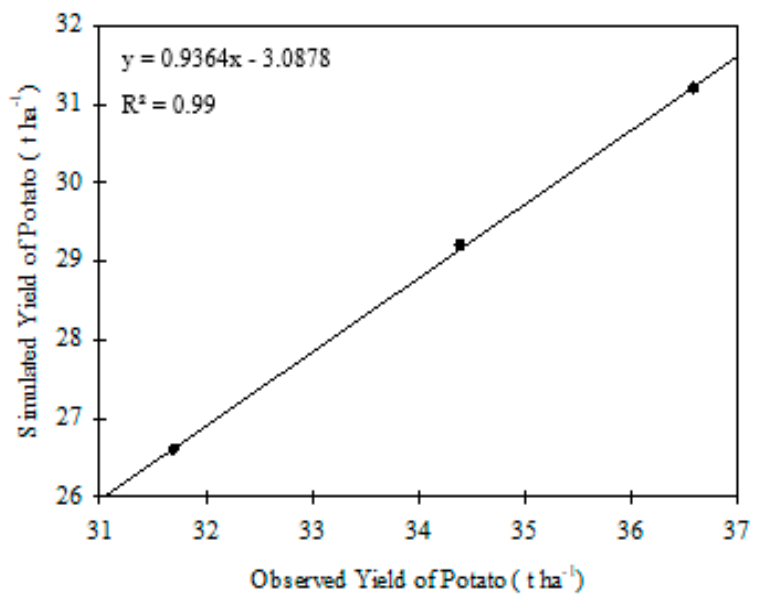

(b)

Figure 7. Cont. 


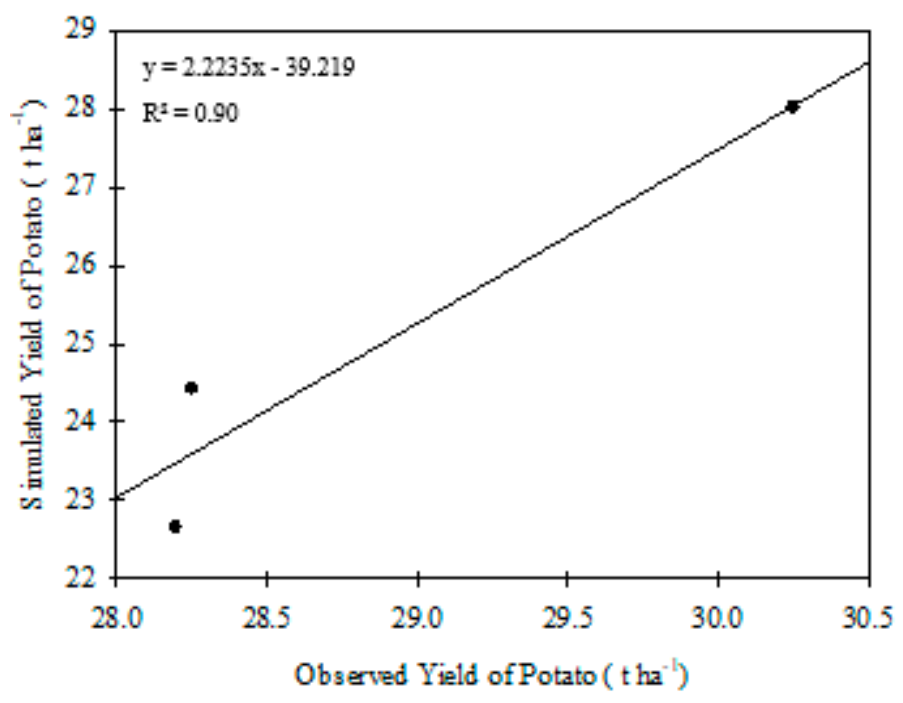

(c)

Figure 7. Correlation between observed and simulated for potato yield under $150 \%$ (a), $100 \%$ (b), and $50 \%$ (c) of ETc.

\section{Conclusions}

The PRD system resulted in saving water with $75 \%$ of ETc which resulted as the same yield under $100 \%$ of ETc for both seasons spring and fall of potato crops. In addition, the subsurface irrigation has a better yield compared to surface irrigation. The PRD was more effective in saving water compare to the conventional full or deficit irrigation. The use of PRD resulted in saving water without any significant decrease in yield. Additionally, this study evaluated the SALTMED model's performance and predicted the moisture, salinity of soil, and nitrogen dynamics. The field experiments were conducted in Saudi Arabia using PRD irrigation techniques under irrigation different levels of percentage ETc. The model showed a reasonable outcome for simulating and predicting soil moisture, $R^{2}$ of more than $90 \%$ as an average of all irrigation levels, and salinity distribution with $R^{2}=93 \%$. The final potato crop yield had $R^{2}=92 \%$ with PRD in arid and semiarid regions. This study used $100 \%$ of ETc for the sitting. The calibration of the SALTMED model concentrated on the soil moisture and salinity, which was a good indicator. The SALTMED model confirmed that predicting soil moisture distribution, salinity, and nitrogen was perfect in predicting the final potato yield of potato.

Author Contributions: A.A.-O. as supervisor of the work and corresponding author, he wrote the final draft of the manuscript, I.L. is setup the experiments and collect data and supervised all work in the field. A.A. run the saltmed program and contributed on first draft of it. M.H.A.E.-W. contributed in first draft of the manuscript. A.O. collect some of data need it. All authors have read and agreed to the published version of the manuscript.

Funding: This research received no external funding.

Acknowledgments: The authors extend their appreciation to the Deputyship for Research and Innovation, "Ministry of Education" in Saudi Arabia for funding this research work through the project number IFKSUHI-014.

Conflicts of Interest: The author declare no conflict of interest.

\section{References}

1. Ragab, R.; Malash, N.; Abdel Gawad, G.; Arslan, A.; Ghaibeh, A. A holistic generic integrated approach for irrigation, crop and field management 2 . The SALTMED model validation using field data of five growing seasons from Egypt and Syria. Agric. Water Manag. 2005, 78, 89-107. [CrossRef]

2. Collins, M.J.; Fuentes, S.; Barlow, E.W. Partial rootzone drying and deficit irrigation increase stomatal sensitivity to vapour pressure deficit in anisohydric grapevines. Funct. Plant Biol. 2010, 37, 128-138. 
3. Dodd, I.C.; Theobald, J.C.; Bacon, M.A.; Davies, W.J. Alternation of wet and dry sides during partial rootzone drying irrigation alters root-to-shoot signalling of abscisic acid. Funct. Plant Biol. 2006, 33, 1081-1089. [CrossRef] [PubMed]

4. Ahmad, S.; Raza, M.A.S.; Saleem, M.F.; Zaheer, M.S.; Iqbal, R.; Haider, I.; Khan, I.H. Significance of partial root zone drying and mulches for water saving and weed suppression in wheat. J. Anim. Plant. Sci. 2020, 30, 154-162.

5. Mattar, M.A.; El-Abedin, T.K.Z.; Alazba, A.A.; Al-Ghobari, H.M. Soil water status and growth of tomato with partial root-zone drying and deficit drip irrigation techniques. Irrig. Sci. 2018, 38, 163-176. [CrossRef]

6. Dry, P.R.; Stoll, M.; Mc Carthy, M.G.; Loveys, B.R. Using plant physiology to improve the water use efficiency of horticultural crops. In Proceedings of the III International Symposium on Irrigation of Horticultural Crops 537, Lisbon, Portugal, 28 June 1999; pp. 187-197.

7. Ragab, R. A holistic generic integrated approach for irrigation, crop and field management: The SALTMED model. Environ. Model. Softw. 2002, 17, 345-361. [CrossRef]

8. Marwa, M.A.; El-Shafie, A.F.; Dewedar, O.M.; Molina-Martinez, J.M.; Ragab, R. Predicting the water requirement, soil moisture distribution, yield, water yield of peas and impact of climate change using SALTMED model. Plant. Arch. 2020, 20, 3673-3689.

9. Alkhasha, A.; Al-Omran, A. Simulated tomato yield, soil moisture, and salinity using fresh and saline water: Experimental and modeling study using the SALTMED model. Irrig. Sci. 2019, 37, 637-655. [CrossRef]

10. Kaya, Ç.I.; Yazar, A. Saltmed Model Performance for Quinoa Irrigated with Fresh and Saline Water in a Mediterranean Environment. Irrig. Drain. 2016, 65, 29-37. [CrossRef]

11. Kaya, Ç.I.; Yazar, A.; Sezen, S.M. SALTMED Model Performance on Simulation of Soil Moisture and Crop Yield for Quinoa Irrigated Using Different Irrigation Systems, Irrigation Strategies and Water Qualities in Turkey. Agric. Agric. Sci. Procedia 2015, 4, 108-118. [CrossRef]

12. Pulvento, C.; Riccardi, M.; Lavini, A.; D'andria, R.; Ragab, R. SALTMED model to simulate yield and dry matter for quinoa crop and soil moisture content under different irrigation strategies in south Italy. Irrig. Drain. 2013, 62, 229-238. [CrossRef]

13. Abdelraouf, R.E.; Ragab, R. The Benefit of Using Drainage Water of Fish Farms for Irrigation: Field and Modelling Study Using the SALTMED Model. Irrig. Drain. 2017, 66, 758-772. [CrossRef]

14. Abdelraouf, R.E.; Ragab, R. Applying partial root drying drip irrigation in the presence of organic mulching. Is that the best irrigation practice for arid regions? Field and modelling study using the SALT-MED model. Irrig. Drain. 2018, 67, 491-507. [CrossRef]

15. Gawad, G.A.; Arslan, A.; Gaihbe, A.; Kadouri, F. The effects of saline irrigation water management and salt tolerant tomato varieties on sustainable production of tomato in Syria (1999-2002). Agric. Water Manag. 2005, 78, 39-53. [CrossRef]

16. Hirich, A.; Choukr-Allah, R.; Ragab, R.; Jacobsen, S.E.; El Youssfi, L.; El Omari, H. The SALTMED model calibration and validation using field data from Morocco. J. Mater. Environ. Sci. 2012, 3, 342-359.

17. Silva, L.L.; Ragab, R.; Duarte, I.; Lourenço, E.; Simões, N.; Chaves, M.M. Calibration and validation of SALTMED model under dry and wet year conditions using chickpea field data from Southern Portugal. Irrig. Sci. 2013, 31, 651-659. [CrossRef]

18. Chauhdary, J.N.; Bakhsh, A.; Ragab, R.; Khaliq, A.; Engel, B.A.; Rizwan, M.; Nawaz, Q. Modeling corn growth and root zone salinity dynamics to improve irrigation and fertigation management under semi-arid conditions. Agric. Water Manag. 2020, 230, 105952. [CrossRef]

19. Noshadi, M.; Fahandej-Saadi, S.; Sepaskhah, A.R. Application of SALTMED and HYDRUS-1D models for simulations of soil water content and soil salinity in controlled groundwater depth. J. Arid. Land 2020, 12, 447-461. [CrossRef]

20. Duisebek, B.; Shahgedanova, M.; Wade, A.; Ragab, R. Testifying SALTMED model using field data in Almaty region, South-east Kazakhstan. EGU General Assembly Conference Abstracts. 2020. Available online: https://ui.adsabs.harvard.edu/abs/2020EGUGA..22.7705D/abstract (accessed on 25 November 2020).

21. Ministry of Water and Electricity. Annual Report; Ministry of Water and Electricity: Riyadh, Saudi Arabia, 2009.

22. Al-Omran, A.M.; Mohammad, F.S.; Alghobari, H.M.; Alazba, A.A. Determination of evapotranspiration of tomato and squash using lysimeters in central Saudi Arabia. Int. Agric. Eng. J. 2004, 13, 27-36. 
23. Allen, R.G.; Pereira, L.S.; Raes, D.; Smith, M. Crop Evapotranpiration Guidelines for Computing Crop Water Requirements; FAO Irrigation and Drainage Paper 56; FAO Food and Agriculture Organization of the United Nations: Rome, Italy, 1998.

24. Loague, K.; Green, R.E. Statistical and graphical methods for evaluating solute transport models: Overview and application. J. Contam. Hydrol. 1991, 7, 51-73. [CrossRef]

25. Al-Omran, A.; Eid, S.; Alshemmary, F. Crop water requirements of date palm based on actual applied water and Penman-Monteith calculations in Saudi Arabia. Appl. Water Sci. 2019, 9, 69. [CrossRef]

26. Brouwer, C.; Heibloem, M. Irrigation Water Management: Irrigation Water Needs; Training Manual No. 3; FAO Food and Agriculture Organization of the United Nations: Rome, Italy, 1986.

27. Zhang, G.; Shen, D.; Ming, B.; Xie, R.; Jin, X.; Liu, C.; Hou, P.; Xue, J.; Chen, J.; Zhang, W.; et al. Using irrigation intervals to optimize water-use efficiency and maize yield in Xinjiang, northwest China. Crop. J. 2019, 7, 322-334. [CrossRef]

28. El-Shafie, A.F.; Osama, M.A.; Hussein, M.M.; El-Gindy, A.M.; Ragab, R. Predicting soil moisture distribution, dry matter, water yield and potato yield under a modified gated pipe irrigation system: SALTMED model application using field experimental data. Agric. Water Manag. 2017, 184, 221-233. [CrossRef]

29. Afzal, M.; Battilani, A.; Solimando, D.; Ragab, R. Improving water resources management using different irrigation strategies and water qualities: Field and modelling study. Agric. Water Manag. 2016, 176, 40-54. [CrossRef]

30. Karandish, F.; Šimůnek, J. A comparison of the HYDRUS (2D/3D) and SALTMED models to investigate the influence of various water-saving irrigation strategies on the maize water footprint. Agric. Water Manag. 2019, 213, 809-820. [CrossRef]

31. Hassanli, M.; Ebrahimian, H.; Mohammadi, E.; Rahimi, A.; Shokouhi, A. Simulating maize yields when irrigating with saline water, using the AquaCrop, SALTMED, and SWAP models. Agric. Water Manag. 2016, 176, 91-99. [CrossRef]

32. Razzaghi, F.; Plauborg, F.; Ahmadi, S.H.; Jacobsen, S.E.; Andersen, M.N.; Ragab, R. Simulation of quinoa (Chenopodium quinoa Willd.) response to soil salinity using the SALTMED model. In Proceedings of the IICID 21st International Congress on Irrigation and Drainage, Tehran, Iran, 15-23 October 2011.

33. Fghire, R.; Wahbi, S.; Anaya, F.; Issa Ali, O.; Benlhabib, O.; Ragab, R. Response of quinoa to different water management strategies: Field experiments and SALTMED model application results. Irrig. Drain. 2015, 64, 29-40. [CrossRef]

34. Rameshwaran, P.; Tepe, A.; Yazar, A.; Ragab, R. The Effect of Saline Irrigation Water on the Yield of Pepper: Experimental and Modelling Study. Irrig. Drain. 2015, 64, 41-49. [CrossRef]

Publisher's Note: MDPI stays neutral with regard to jurisdictional claims in published maps and institutional affiliations.

(C) 2020 by the authors. Licensee MDPI, Basel, Switzerland. This article is an open access article distributed under the terms and conditions of the Creative Commons Attribution (CC BY) license (http://creativecommons.org/licenses/by/4.0/). 